\title{
Internationalization Via Instagram: An Exploratory Study of Small and Medium Enterprises
}

\author{
Suku Sukunesan* \\ Swinburne Business School, Swinburne University of Technology \\ E-Mail: ssinnappan@swin.edu.au \\ Christopher Selvarajah \\ Swinburne Business School, Swinburne University of Technology \\ E-Mail: cselvarajah@swin.edu.au \\ Zelda Mellström \\ Newcrest Mining Melbourne \\ E-Mail: zelda.mellstrom@hotmail.com,
}

\begin{abstract}
This study used content analyzed ten Australian Small and Medium Enterprises (SME) sites for their brand awareness, communication, information, integration and cultural awareness to examine how best they use Instagram to internationalize. In this study, the internationalization process was provided through engaging a 3-stage internationalization process model (no plans to export, potential exporter, exporters) and, training outcomes were identified. Findings showed that owing to reduced barriers of engaging with overseas market, SMEs with the higher brand and cultural awareness, and acceptable online communication practices were primed for internationalization while SMEs who had poor business integration were negatively viewed for internationalization. These findings have implications for theory and practice.
\end{abstract}

Keywords: Instagram, SMEs, Internationalisation, Customer created content, Web 2.0, Leapfrogging

\section{INTRODUCTION}

Small and Medium Enterprises (SMEs) play a major role globally. They represent $90 \%$ of businesses and more than $50 \%$ of employment worldwide (World Bank, 2020). GDP contribution to the national economy is also generally high. For example, the 
SMEs contribution to GDP accounts for more than half for countries such as the USA, South Korea and Australia (Al-Abri, Rahim, \& Hussain 2018; Bloom 2017). Exporting is a feasible way for these companies to change from stumbling domestic sales to growing international markets while preserving flexibility and minimizing risk and costs associated with other international expansion modes (Hultman, Katsikeas \& Robson, 2011; Morgan, Katsikeas \& Vorhies, 2012).

Impact to the overall economy and footprint of these SMEs to international commerce are undeniable as SMEs (1) provide a major foundation for innovation growth to be globally competitive (Johnson, 2010; Son \& Benbasat, 2007; White, Daniel, Ward, \& Wilson, 2007), (2) successfully compete with the larger businesses with fewer resources (Li, Su, Zhang, \& Mao, 2018; Cha et al., 2015; Daniel \& Wilson, 2003), and (3) innovate in order to achieve a competitive advantage and provide more options for the customers (Workfast.com.au, 2017).

Although there is extensive literature on the internationalization process of SMEs, especially with networking (e.g. Loane \& Bell, 2006; Sharma \& Blomstermo, 2003; Sternad, Mundschutz \& Knappitsch, 2013; Zhou, Wu \& Luo, 2007), studies relating to SME development using digital technology is still in the infant stage (Bianchi, Glavas \& Mathews, 2017; Grochal-Brejdak \& Szymura-Tyc, 2018; Li et al., 2018; Louart \& Martin, 2012) as this is a relatively new export enhancing platform. Echeverri and Skålén (2011) are of the view that empirical research has not been geared towards studying the micro practice of interactive value formation. In this study, Instagram as an instrument to enhance interactive value formation is explored.

In the following sections, we will analyze the evolving nature of social media in support of business development and the role of Instagram, as a business tool, is increasingly being used in SME internationalization. In selecting an appropriate framework to provide a process model for the internationalization of SMEs, a number of models were identified and analyzed. This is discussed in the section 'internationalization theories'. In this paper, we have referred to Selvarajah, Sukunesan, Le, Le, and Meyer (2015) work on SME tiers for a staged SME internationalization process to support Instagram usage.

\section{Instagram as an SME Business Tool in Social Media}

Changes in social, technological and economic environments (Li et al., 2018; Chong, Bian, \& Zhang, 2016), together with fewer limitations in international trade through technology (Li et al., 2018), has encouraged SMEs to internationalize as means for survival. Adopting suitable platforms such as the internet has been a game-changer (Sinkovics \& Bell, 2005). The internationalization of these small firms has been heavily influenced by trends towards the globalization of business activity and the impact of 
communication technologies and new processes (Ghirmai, 2011). The internet offers direct and immediate foreign-market entry, even for the smallest firms to communicate at an international level, and a possibility to remove some or all barriers an SME can face while managing an international business (Bell, 2010). Technology enables faster internationalization (Oviatt \& McDougall, 2005) and that the speed of internationalization has been further accelerated by newer and more modern internet and mobile-based technologies (Shenglin et al., 2018).

Social media has a significant influence on a brand's success, and increasingly more businesses are exploiting social media as a part of their business operations and brand building (Oztamur \& Karakadilar, 2014; Gallauger \& Ransbotham, 2010) because of the rapid penetration into society (Dickey \& Lewis, 2010). More than half of world's population, 3.8 billion people are active on social media (Hootsuite \& We are Social, 2020), and one of the main drivers behind this continued growth is the love for visual content (Sensis, 2017) such as video, image and rich text. Since an increasing number of individuals are online soliciting information and engaging in purchasing decisions, it is essential for businesses to understand how social media is used and to capitalize on this opportunity (Numilla, 2015). However, despite the evidence and growth of online business intentionally (Meltzer, 2015), there is evidence that SMEs are failing to take advantage of it (Sensis, 2017, Deloitte, 2017, Deloitte 2019). Two of the main reasons are, they do not see any benefit from social media and that they lack understanding of social media.

One of the social media platforms that have grown tremendously, thriving on visual content, is Instagram. Findings from Pew Research (2018), based on the American social media platform usage, also suggested a similar trend. Their studies show Instagram enjoying a rapid growth rate as compared to other social media platforms which have started to plateau, such as Facebook. This application has become a popular platform for businesses ability to narrate visual storytelling rather than simply presenting written information. Research shows that Instagram has a higher level of usage for engagement, co-creation and interaction compared to other social media platforms (Virtanen, Björk \& Sjöström, 2017). Hence, the focus of this study is to examine how selected Australian SMEs have leveraged Instagram as a business platform to internationalize and where the knowledge gaps are for remedial attention and training.

\section{THEORETICAL BACKGROUND}

With the growth of high-tech industrial markets, competitive success is a factor of continuous technological innovations where organizations have to rely on external relationships and networks to enhance its knowledge domains while speeding up newer, 
better and more efficient innovations (Martin-de Castro, 2015). This openness and absorptive capacity are also discussed by Goldemberg (2011, p.135) where he refers to leapfrogging in industrialized nations involving "continuous, incremental process, eventually leading to breakthroughs or revolution.." This notion of absorptive capacity is well embedded in entrepreneurship. Schumpeter (1942), an early proponent of entrepreneurship, expresses that technological leadership is when competitors are willing to take more risks and adopt new technologies to leapfrog to higher competitive levels. Schumpeter talked about 'gales of creative destruction' as a condition for technological leapfrogging. As globalization intensifies driven by new technological development, this notion of leapfrogging and absorptive capacity is emphasized by Chen and Li-Hua (2011, p.93); stresses the importance of "keeping up with the speed of the technological change and the emerging new global paradigms of the business environment."

In this paper, we propose that commercial knowledge is advanced by new interactive information platforms such as Instagram. As a way forward in advancing this knowledge base, the interactive value formation framework (IVF) for understanding resource integration to create value for the organization and how this takes place in practice (Echeverri \& Skålén, 2011; Makkonen \& Olkkonen, 2017) is applied. Theoretically, the study is based on practice theory.

\section{Interactive Value Formation (IVF) as a Concept}

Interactive value formation stipulates that value is co-created during the interaction between the provider and the customer (Prahalad \& Ramaswamy, 2004; Ramírez, 1999; Vargo \& Lusch, 2004). In contrast to conceptualizing value as embedded in the product, this view holds that providers co-create services and products in collaboration with their customers.

While co-creation has dominated marketing service research (Sthapit \& Bjork, 2018), there are very few studies that look at co-destruction, the negative aspects of IVF (Echeverri \& Skålén, 2011). Ple (2017) explains that co-creation and co-destruction coexist, but because of the over-emphasis on co-creation in academic literature, there is bound to be a perceived value difference that could affect the understanding of IVF. Makkonen and Olkkonen (2017), see the third dimension of IVF, a neutral or balancing dimension 'no-creation' in terms of inter-organizational relationships. In this neutral position, no-creation, "resource integration and the respective value-in-context remain unrealized" (Sthapit \& Bjork, 2018, p. 2). IVF thus provides a dynamic interchange between value co-creation, no-creation and co-destruction.

\section{Practice Theory}


To provide a framework to explore Instagram as a micro practice of interactive value formation, we draw on practice theory to drive the current research. The interactive value formation at the provider-customer interface has been studied from the theoretical lens of practice-theory perspective (see Echeverri \& Skålén, 2011; Jarzabkowski \& Bednarek, 2018; Makkonen, Olkkonen, \& Halinen, 2012; Perera, Anger, \& Klein, 2018). In this paper, as Shove (2004), Perera et al., (2018), Ropke (2009) have argued practice theory can be applied to understand environmental consumption, we apply practice theory to the understanding of internationalization of SME exports via Instagram usage. In doing this, a central phenomenon in practice theory, habitus, is emphasized. Habitus is the way individuals perceive the social world around them and thus is said to shape the social actions of an individual (Lizardo, 2004).

Though the concept of habitus, the cornerstone in practice theory, has been used as early as Aristotle (Nederman, 1990; Rodrigo, 2011), it was Pierre Bourdieu in 1977 who emphasized a theory of practice in the publication 'Outline of a Theory of Practice' and associated the concept with addressing agency and structure as two-valued factors shaping habitus (Bourdieu, 2013). Thus, generating a structural position and being action-oriented are integral parts of a habitus. This notion of action is possible and understood in the context of common and shared practices, provides the basis through which social order is informed by these practices (Bourdieu, 1977; Foucault, 1977; Giddens, 1994).

It is this concept of habitus, within practice theory that Shove (2004), discusses the integration of images, meaning, forms of competence, and materials as constituting a practice. Social media platforms thrive on these forms of practice encouraging and supporting users to create dialogue through content which Bruns (2007) calls produsage. Produsage is a concept built on user-generated content (UGC) which is generally applied to define the diverse types of media content that are openly available and generated by end-users (Kaplan \& Haenlein, 2010). Fuelled by the growth of devices, social media platforms rely on UGC luring and promoting users to create, share and consume content. These platforms allow SMEs to operate alongside more established businesses (Boyd \& Ellison, 2008; Michaelidou, Siamagka \& Christodoulides, 2011) by establishing online communities.

\section{Internationalization Theories}

The biggest challenge in the internationalization of sustainable business is the formulation of a perfect operational strategy to optimize investor success (Gullen \& Parboteeah, 2010). Though there are numerous propositions aimed at explaining critical factors that drive the internationalization of business, there is no single measure that could be applied to the understanding of these factors to be considered before venturing 
into international business (Brook et al., 2011; Daniels et al., 2015; Morrison, 2011). Business internationalization theories, such as Dunning's Eclectic Paradigm (Narula, 2010; Schellenberg, Harker, \& Jafari, 2018), Kruger's First Mover Advantage Theory (Suarez \& Lanzolla, 2008), Vernon's Product Lifecycle Theory (Davi, 2002), and the Uppsala Internationalisation Model (Schellenberg et al., 2018), as theories have been used widely to explain the processes of business internationalization. However, there have been criticisms, including the inability of the earlier three theories in addressing problems of cultural differences and ignoring internal factors needed by companies to manage international activities (see Buckely et al., 2009). The Uppsala Model has contributed to a broader understanding of international processes of companies and is the most cited also suffers from describing the totality of the internationalization process as its original unit of analysis (Forsgren, 2016). It does not provide answers as to why franchising, licensing and strategic alliances or how the changes in the business environment in the last 20 years impact on the theory's development (Doole \& Rowe, 2008; Forsgren, 2016, Coudounaris, 2018). In fact, Coudounaris (2018), are of the view that the Uppsala model does not apply as an SME internationalization pathway theory in their study.

Therefore, with SME internationalization featuring as a strong competitor to the traditional foreign direct investment-driven by large global corporations, several issues regarding the relationship between business networks and forms of internationalization have to be considered. This has become even more critical with the advent of ecommerce and the popularity of web-based communication platforms. In this paper, we progress with the view that similar to Coudounaris (2018), new internationalization pathways for exporter groups need to be explored. In doing so, the model by Selvarajah et al. (2015) was chosen as it described the totality of the internationalization process as the unit of analysis, addresses cultural differences and the internal factors as development stages needed by companies to manage their internationalization. This becomes more evident with new technological platforms to support SME internationalization.

\section{METHODOLOGY}

The purpose of this study is to see how SMEs use Instagram as a platform to internationalize before assigning them to one of the three tiers mentioned earlier. To do so, we have used Australian SMEs to assess how they leverage the features of Instagram to reach out and engage to customers similar to well-established businesses. In order to do this, we have utilized Selvarajah et al. (2015) 3-stage process model, the concept of technological leapfrogging to enable SME digital engagement, and Instagram as a platform for SME internationalization. Each Australian SMEs Instagram account was 
content analyzed based on five international marketing dimensions and their categories; communication, business integration, marketing reach to customers and facilitation of commerce transactions. The contributing authors to the five international marketing dimensions and categories are provided in Appendix Table 1

\section{SME Internationalisation Framework}

A nationwide survey in Vietnam ${ }^{1}$ and the 3-stage model on SME internationalization readiness was tested by Selvarajah et al. (2015) and published in Selvarajah, Le \& Sukunesan (2019). This model is now empirically tested and adopted in studying Instagram, internet-based social media technology, used to enhance export performance in this paper.

The aim of Selvarajah et al. (2015, p.5) study on Vietnamese SME performance was to identify the "key success factors for organizations involved in exporting, across the major industries currently involved; allowing targeted training programs to be implemented in different regions to address skill gaps." The findings from the study implied three groups or levels of SMEs; SMEs with no plan to export, SMEs with a plan to export and current exporters. The outcome influence of the study was the acknowledgement that in Vietnam, with adequate and targeted training, the capacity of SME groups could be enhanced in a stage-process approach (Selvarajah et al., 2019). A 3-stage process model was established, which highlighted the particular training needs of SME internationalization groups. In the current paper, potential exporters are divided into non-exporters and potential exporters who provide a fine-grain analysis of SME exporters, SME potential exporters and SME non-exporters.

\section{SMEs with no plan to export}

The manager's attitudes and perceptions of non-exporting are built on the absence of self-efficacy, which decreases their export commitment (Acedo \& Galan, 2011; Karjaluoto \& Huhtamaki, 2010; Yeoh, 2005). Consequently, it has been suggested that self-efficacy is expected to disintegrate any external applied-inducements. Instead of offering basic training on export, training has to mainly address the needs of selfefficacy.

\section{SMEs with a plan to export}

The manager's attitudes and perceptions are notably associated with export commitment, signifying that external inducements and training assets need to be applied to guarantee that export commitment is being built. Furthermore, risk assessment

\footnotetext{
1 The collaborative project 'Capacity Building to Accelerate SME Export Performance' between the AED, Vietnam and Swinburne University of Technology and funded by the Australian Department of Foreign Affairs and Trade's Public Sector Linkage Program (PSLP).
} 
strategies are essential managerial determinants (Kuivalainen et al., 2010; Cicic et al., 2002), which increase proactive planning of business strategies where explicit training needs to be targeted. Additionally, it is significant to offer training to improve networking strategies (Matenge, 2011), organizational export commitment (Inkster, 2008; Yip, Biscarri \& Monti, 2000) and factors of creating proactive business strategies (Shamsuddoha, Ali \& Ndubisi, 2009; McDougall \& Oviatt, 2000). This is important to develop an innovation strategy, which will result in export activities.

\section{Current exporters}

In regard to current exporters, initiatives for training to maintenance networking and developing proactive business strategies are seen as vital in developing and uphold export performance. Training should furthermore be instituted in growing international business knowledge (Yu et al., 2005) and self-efficacy (Acedo \& Galan, 2011) as these impacts organizational export commitment and increases the wish to develop networking behaviour (Selvarajah et al., 2019). Training to comprehend and manage mental distance, as a phenomenon for improving the innovation strategy of export performance, is significant to both current exporters and SMEs with a plan to export.

A summary of the described 3-stage process model is presented in Figure 1, presented below.

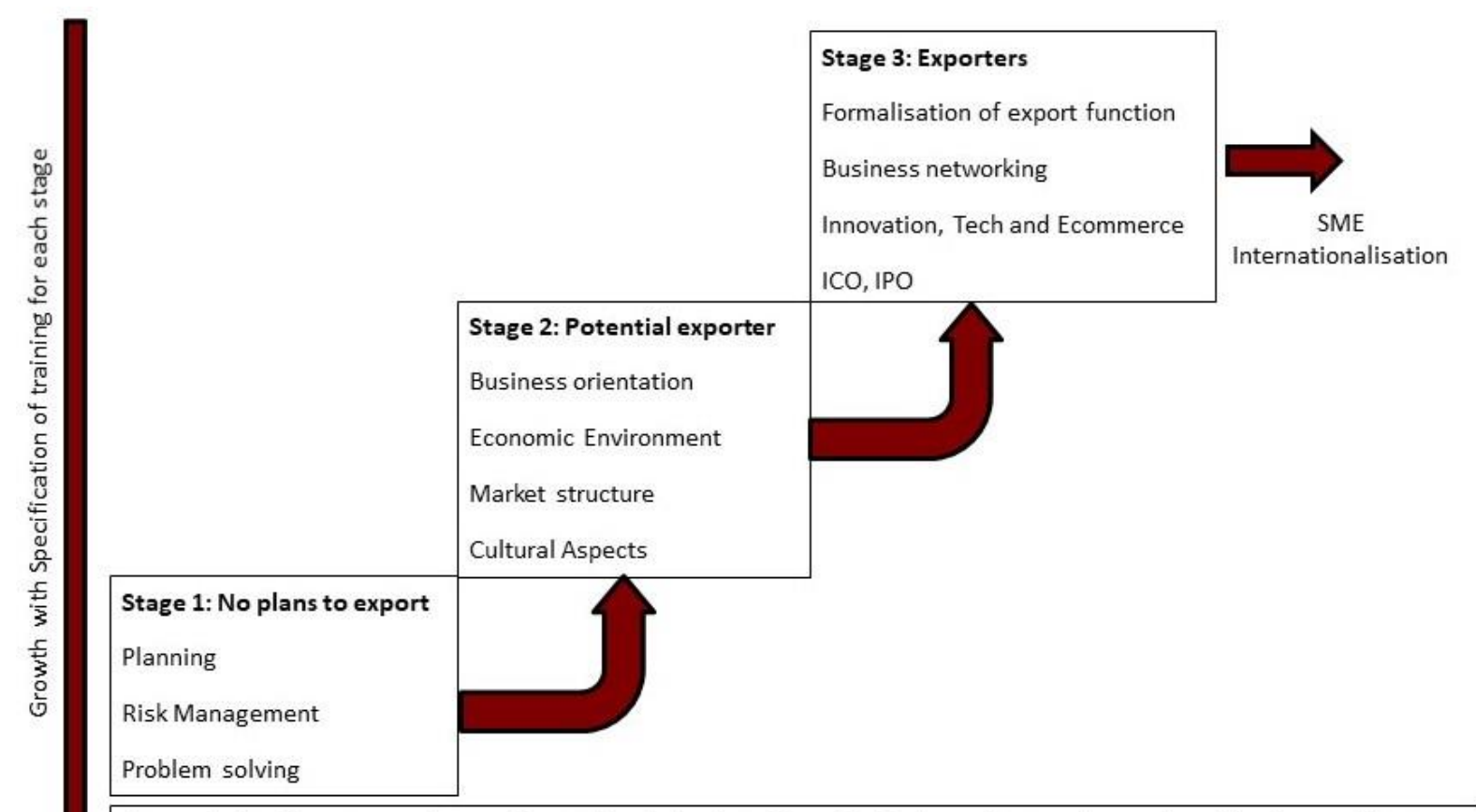

Base training: Export commitment, Networking behaviour, Proactive Business Strategy, Innovation Adoption and Strategy

Stages of SMEs

Source: Selvarajah et al., 2015, p.14

Figure 1 Three-Stage Process Model for SME Internationalization 
An important outcome of the Selvarajah et al. (2015) study, demonstrated in Figure 1 is the readiness of SMEs in the internationalization process. Capturing the position of these SMEs within a 3-stage developmental process does suggest that leapfrogging as a theoretical concept could be applied to enhance their export performance. Briefly, in the next section, we describe what technological leapfrogging is and how this aids technological disruption and supports SME development.

\section{Technological Leapfrogging and SME Development}

Studies on leapfrogging as a theoretical concept is still at an infant stage, and the majority of the studies reported have been based on businesses in developing countries (see, Asia News Monitor, 2018; Leonard, 2012; Chen, \& Li-Hua 2011; Clark, \& Isherwood, 2010; Cleverley, 2009; Anonymous, 2008; Menon, 2006; The Economist, 2006; Negroponte, 1991).

Clearly, the cited references are of the view that technology is spearheading global commerce and many developing countries are at the forefront of this development (Anonymous, 2008; The Economist, 2006). Global developments have historically followed the four industrial revolutions (see Schwab, 2016). The First Industrial Revolution (IR1) generally spanned the $19^{\text {th }}$ century used water and steam to mechanize production, the Second Industrial Revolution (IR2) generally covered the $20^{\text {th }}$ century used electricity to create mass production. The Third Industrial Revolution (IR3) spanned from approximately after World War 2 to the beginning of the $20^{\text {th }}$ century used electronics and information technology and the Fourth Industrial Revolution (IR4) which is current is building on IR3 characterized by a fusion of technologies that engage artificial technology and mechanization. There is overlap between the revolutions, especially between IR3 and IR4.

The IR3's shift to the IR4 has seen the emerging technologies for sustainable smart communities where machines and artificial intelligence play a significant role in enhancing a nation's productivity and wealth creation (Ferrara, 2015). The European Union has passed legislation (European Commission, 2012) supporting the concept of sustainable smart cities and communities where "...a smart city...uses digital technologies to enhance performance and well-being, to reduce costs and resource consumption and to engage more effectively and actively with the citizens." Similarly, Australian initiatives with regard to IR4 is "..creating an environment that will allow businesses to grow, explore new models and embrace technologies" (DISER, 2020).

Schafer (2018) emphasizes that developing an environment appropriate for new technologies invariably supports the IR4. It is no wonder that SMEs have been mentioned as part of the 'European dream' (Rifkin, 2005). SMEs are seen as the lifeblood of economies, going where the larger companies fear to tread, quickly 
identifying new niches and rushing to exploit them, and creating jobs wherever they go (Leonard, 2012). It is with this realization that SMEs are viewed as the major driving force of disruptive technology in the new era of IR4 (Chen, 2017). Also, in most countries, SMEs form the bulk of businesses and revenue generation for nations (Sternad, Mundschutz \& Knappitsch, 2013). It is this enhancement of SMEs, engaging in technology diffusion to all communities, enabling them to leapfrog traditional development that this paper seeks to address.

\section{Digital Engagement and Social Media Enabled Business Operations}

Digital engagement has become a significant component of the success of SMEs (Deloitte, 2017). Digital tools can facilitate businesses to leapfrog to attain improvement in operational procedures and help with development as it is strongly connected with innovation, revenue growth and expanded market reach (Samson, Mehta \& Chandani, 2014). Consequently, it is essential for SMEs to consider how digital tools might be used for their business to obtain the full benefits of technology. Deloitte (2017) has established a digital engagement 'ladder', which positions SMEs on their digital engagement. The digital engagement ladder measures digital engagement through the use of technology, such as social media, websites, email, online marketing and data analytics. The three top benefits to digital engagement were identified as increased sales, revenue and access to new customers allowing SMEs to promote brand awareness, improve their brand image and also compete with larger businesses. The survey conducted by Deloitte (2017), of 1500 Australian SMEs, showed that the half of SMEs were 'advanced' or 'high' in their digital engagement in 2017, compared with $43 \%$ in 2016. A consequent study involving over 1000 SMEs in the US showed similar results (Deloitte, 2019). These studies identified that businesses with advanced digital engagement were more likely to recognize specific benefits with digital tools compared to businesses with basic digital engagement.

It implies that businesses with higher levels of digital engagement are more likely to be agile to identify opportunity and reach new customers. Large businesses are known to struggle with such agility due to their bureaucratic processes and culture. SMEs with higher digital engagement is also better in identifying the benefits of their digital tools with shorter learning curves due to the need to innovate. Deloitte (2017) has further suggested that SMEs with an advance level of digital engagement are 50\% more likely to grow revenue and earn $60 \%$ more revenue per employee. In order to establish better digital engagement among SMEs, improving the education of business decision makers is therefore crucial. Time pressure is a constant challenge for business owners. However, investments in building digital skills will help raise confidence around using and implementing digital tools in their day-to-day operations. More knowledge and 
improved skills can support trust-building in digital tools and help identify potential issues and perceived barriers to the usage of digital technology.

Social media has been a major part of SMEs digital engagement. It is certainly the key channel for reaching customers and has grown to become a vital strategic tool for SMEs as it could be used for market research, promotion and advertising, branding, strengthening customer relations and in sales (Dutot \& Bergeron, 2016; Sensis, 2017). Through social media channels, SMEs seek customer engagement and increased brand awareness. It provides a quick and efficient way to reach their target audience, and increasingly more businesses see the possibility of having social media as a channel for customer service (Numilla, 2015). As described earlier, social media adoption in the USA which mimics most businesses in the developed nations are moving, in the last few years from older media platforms such as Facebook, to Instagram with a focus on visual content in the last few years (Pew Research, 2018). We are, therefore, of the view that many emerging nations will also follow suit as technology usage develops. Thus, though there are several types of social networking sites, this paper will focus on Instagram.

\section{Instagram as a Platform for Global presence}

Instagram was launched in 2010 by Mike Krieger and Kevin Systrom (Numilla, 2015), is a free mobile photo-sharing application, which markets as a channel and allows users to transform the image into memory. Facebook bought the USD 1 billion application in 2012 (Lee et al., 2015) and in September 2017, Instagram had 800 million active users around the world, which is 200 million more active users since December 2016 (Statista.com, 2018). Instagram is four years younger than Twitter but has already surpassed Twitter's registered users, and the application provides 58 times more engagement to brands than Facebook and 120 times more than Twitter (Numilla, 2015).

There are two primary features on Instagram; it operates as a social network for sharing images, and it allows users to edit their photos and videos. In general, Instagram allows smartphone users to upload pictures and videos to their profile (Numilla 2015; Ridgway \& Clayton, 2016). Instagram can be accessed through its website where users can view their feed, profiles and comments; however, they can only post content through a mobile application (Amancio, 2017). Anyone can create an account, share content, follow other users, such as businesses, brands and celebrities. The various features that are possible on Instagram are featured in Table 1. 
Table 1 Instagram Features

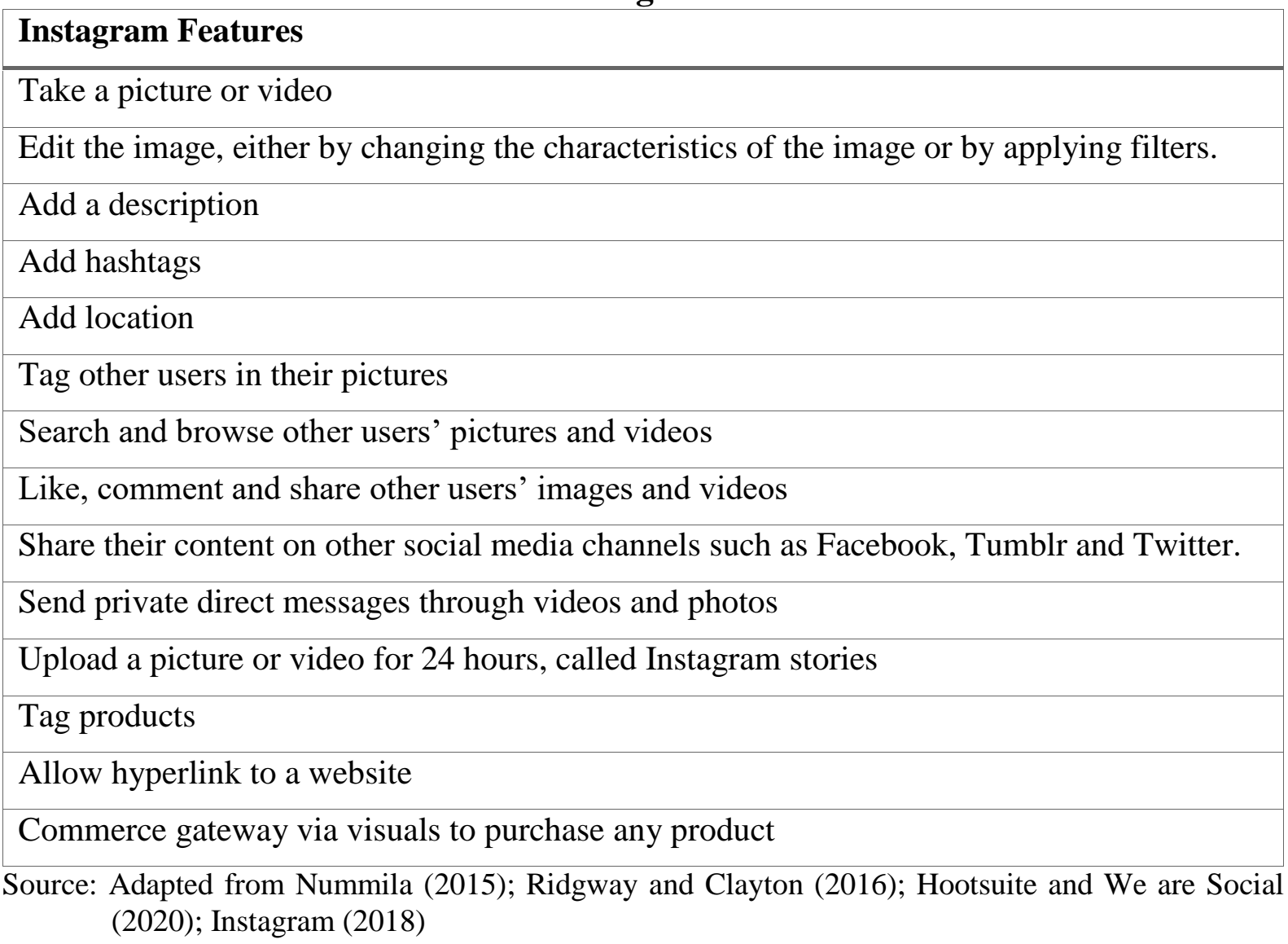

Many businesses use Instagram to create business-consumer networks in order to make their products more applicable to consumers lifestyles and values. Moreover, it has been suggested that businesses with a high level of attendance on Instagram are expected to have more consumers following them and their products, which makes all brand-related events, updates and photos more easily shared, disseminated and talked about (Ting, Cyril de run \& Ling Liew, 2016).

Other interesting features of Instagram is the Instagram stories. The 'stories' feature is highly valuable for businesses as they can show what content they want their users to see first. The story highlights can be viewed as 'movie trailer' for the user's Instagram feed and is a creative way of expressing users or brands' personality, demonstrate products, drive traffic or market the business (Gilbert, 2017).

Instagram has also become a platform to elevate the shopping experience allowing businesses to tag their products in posts to connect with customers in a new, immersive way and makes shopping less transactional and more actionable (Instagram, 2018). This feel of discovery goes even further by providing users with a visual storefront to discover new products from businesses they are following. After users have discovered more about a product, like through a shopping post, they can tap 'show now' to go straight to the mobile business site. It allows users to go from being motivated to seek 
more information and acquisition in only a few taps (Instagram, 2018). This process is facilitated by the geotag and hashtags \#. Geotagging images allows all images with the same geotag to be gathered in the same place on Instagram while hashtags are a way of emphasizing a word or a phrase by placing it behind a \# (Buinac \& Lundberg, 2016). By using popular hashtags with the image, businesses are better placed to reach more people.

Consumer's love for visual content (Sensis, 2017) has, for example, increased the usage of visual-content internet platforms globally, such as Instagram from 800 million to 928 million and Snapchat from 255 million to 381 million in 24 months (Hootsuite and We Are Social, 2020). Nummila (2015) suggests that the key to successful branding on Instagram is using images and text together in a clever way to tell an interesting story. By starting a conversation, businesses can assist in creating a sense of community (Nummila, 2015) where businesses can find out what the customers would like to hear and see and what might be found valuable, enjoyable and interesting (Virtanen, Björk \& Sjöström, 2017). SMEs could leverage Instagram to internationalize and reach out to customers punching above their weight competitively against more established larger businesses. By investing strategically into Instagram SMEs can build stronger brand awareness, integrate their communication channels, share product information with customers and facilitate commerce transactions as well.

However, not all SMEs understand social media or Instagram well to reap the benefits and leverage it as a platform. To enable this connection, Selvarajah et al. (2015) research on Vietnam's SMEs 3-stage process model, establishes the training needs in three categories of SME internationalization groups (current exporter, potential exporter, non-exporter). This model emphasizes the key success factors for exporting; however, the model does not include social media, such as Instagram as an internationalization tool, which this study contributes.

\section{Content Analysis}

In this study, we have used content analysis methodology (Zhang \& Wildermuth, 2005) to understand individual SME behaviours (Saunders, Lewis \& Thornhill, 2007) in leveraging Instagram to internationalize. This approach is similar to Lin, Lu, Hsieh \& Liu, (2018) and, Bhattacharyya \& Agbola (2018) where content analysis evaluation was carried out through systematic observation, recording, description and analysis.

We employed a convenient sampling approach to select several Australian based SMEs active on Instagram. The state government business arm, Business.vic.gov.au and StartupVictoria.com.au, were approached to obtain businesses that used Instagram as a business channel. The authors were provided with 12 suggestions where 10 SMEs as listed in Table 2 were selected FrankBody.com, KeepCup.com, PressedJuices.com.au, 
ThankYou.co, LovingEarth.net, LiartheLabel.com.au, LonelyKidsClub.com, HLSK.com.au, Bisonte.com.au and VegeThreads.com.

Table 2 Brief Information of the Ten Selected SMEs

\begin{tabular}{|c|l|l|}
\hline No & \multicolumn{1}{|c|}{ Selected SMEs } & \multicolumn{1}{|c|}{ Brief description of the business } \\
\hline 1 & FrankBody.com & $\begin{array}{l}\text { Frankbody is a cosmetic business which uses coffee powder as } \\
\text { the main ingredient for the skincare line. }\end{array}$ \\
\hline 2 & KeepCup.com & $\begin{array}{l}\text { KeepCup sells reusable coffee cups using sustainable } \\
\text { manufacturing practices. }\end{array}$ \\
\hline 3 & PressedJuices.com.au & $\begin{array}{l}\text { PressedJuices is in the health and wellness industry, selling } \\
\text { handcrafted cold-pressed juices. }\end{array}$ \\
\hline 4 & ThankYou.co & $\begin{array}{l}\text { Thankyou is a social enterprise that was founded to tackle } \\
\text { global poverty. }\end{array}$ \\
\hline 5 & LovingEarth.net & $\begin{array}{l}\text { LovingEarth makes chocolate from fair trade cacao which has } \\
\text { been grown by the Ashaninka community in Peru. }\end{array}$ \\
\hline 6 & LiartheLabel.com.au & $\begin{array}{l}\text { LiartheLabel makes affordable eco-clothing, mainly women's } \\
\text { swimwear. }\end{array}$ \\
\hline 7 & LonelyKidsClub.com & $\begin{array}{l}\text { Lonely Kids Club is a clothing label offering boutique } \\
\text { experience. }\end{array}$ \\
\hline 8 & HLSK.com.au & $\begin{array}{l}\text { HSLK produces in-house handcrafted jewellery using ethically } \\
\text { sourced materials. }\end{array}$ \\
\hline 9 & Bisonte.com.au & $\begin{array}{l}\text { Bisonte sells handcrafted leather goods and accessories for men } \\
\text { and women. }\end{array}$ \\
\hline 10 & VegeThreads.com & $\begin{array}{l}\text { VegeThreads manufactures clothes for everyday wear by using } \\
\text { organic and eco-friendly materials. }\end{array}$ \\
\hline
\end{tabular}

In this study, the data has been analyzed both qualitatively and then quantitatively, authors have used the Instagram checklist to score the SMEs. This data technique is called optimal scaling and allocates numerical values to the observation groups with a method that exploits the relation among the observations and the data analysis model whilst respecting the measurement appeal of the data (Saunders, Lewis \& Thornhill, 2007). Optimal scaling allows researchers to better identify the average performance of all businesses for each of the investigated areas, to make enhanced and justifiable conclusions. Utilizing these scores, the SMEs will be categorized into tiers identifying what kind of training they need to improve their performance on Instagram.

\section{ANALYSIS AND RESULTS}

The ten selected Australian SMEs were content analyzed using 5 international marketing dimensions which were highlighted in the extant literature and referenced in Appendix Table 1. These five dimensions are Brand Awareness, Communication, Information, Integration and Cultural Awareness. Each core dimension had categories and sub-categories, respectively. As recommended by (Hosni, 2020, cone Naaman, 
2010) for each category, a maximum score of 5 is awarded by each of the three authors, and two independent reviewers and each category that had different score was deliberated to remove coder bias if an SME met the criteria completely as opposed to a zero when authors fail to find any evidence. In the following sections, the 5 dimensions are analyzed, and the results reported.

\section{Brand Awareness}

This dimension related to how the Instagram site looks and communicates. Brand awareness facilitates penetration of products into foreign markets which is one of the major pillars to internationalization. Given the visual prowess that the Instagram platform facilitates, it is important to have vivid content to 'shout out' when it comes to content appeal (Holliman \& Rowley, 2014; Ashley \& Tuten, 2015, Hellberg, 2015, Virtanen, Björk \& Sjöström, 2017). This would imply a mix of content suited to market the respective products (Nummila, 2015), appropriate choice of the colour scheme (Le, 2015, Aslam, 2006) and choice of influencers (Wong 2014; Veriman, Cauberghe and Hudders, 2016; Talavera, 2014) as a brand or product ambassadors possibly popular amongst the target audience.

The average score for the brand awareness dimension is 2.82 as shown in Table 3 while the sub-dimensions are 3.20 (Content marketing/Visual communication), and 2.45 (Influencer marketing) are in Appendix Table 2. Most of the businesses had crispy, good quality images on their Instagram profile; however, two of the companies had some areas for improvement. FrankBody, PressedJuices, LovingEarth, ThankYou and VegeThreads are perceived to have done their framing well, shown creativity and have included pictures and images.

Examples of framing from LovingEarth, PressedJuices and ThankYou are presented in Figure 2 below. Nummila (2015) suggests that it is significant to always tell a story on businesses' Instagram profiles and creating a connection between the product and the viewer's personal life. Adding both personal and fun images in association with the brand can help support the company to stand out and connect with their followers on an individual level. Nummila (2015) furthermore suggests that there should be a balance in the shared content on social media. Ten percent of the content should be promotional, 30 percent owned, and 60 percent curated in order to produce the right sort of diversity to the content.

Owned content is, for example, SMEs' own images that are hosted on their own domain, such as photos or videos. The reason for only suggesting 30 percent owned content is because it can be boring for the audience to only see content where the brand is talking about itself (Bevilacqua, 2014). 

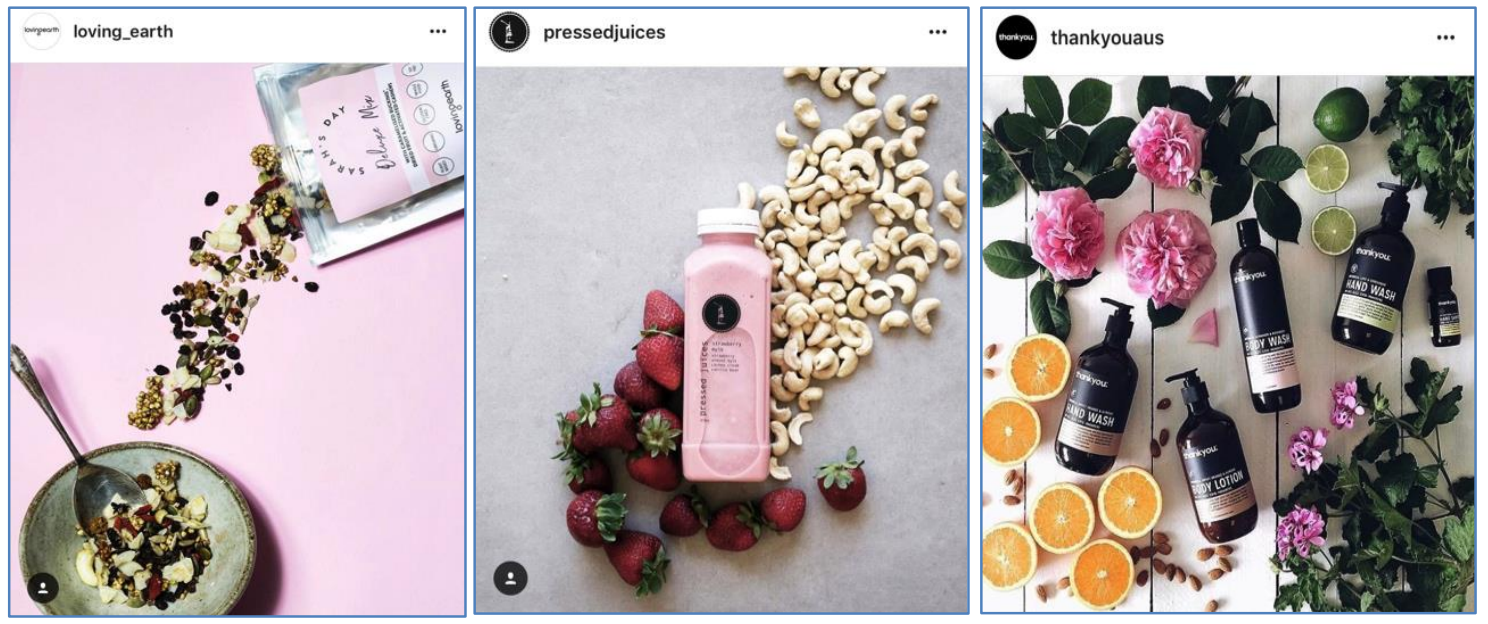

Source: Instagram 2019c to 2019e

\section{Figure 2 Examples of Framing}

Curated content is content that has been created by others, yet relevant to the business' brand, industry and community (Bevilacqua, 2014). Since UGC is media content that is created or produced by the general public (Daugherty, Eastin \& Bright, 2008), this can be viewed as curated content. On Instagram, this can, for example, be seen as content with quotes.

Promotional content is content with a call to action, such as ' 30 percent off all purchases', 'sign up for a demo', or 'try our product for 14 days'. The reason for only having $10 \%$ promotional content is because if a business is trying to sell too much on social media, it can be a turnoff (Bevilacqua, 2014). When it came to the mixing of content LovingEarth had a good mix of content and is the only business that had 10 percent promotional content relating to their new products, $30 \%$ owned content (created by themselves) and $60 \%$ curated. FrankBody had a good mix of content, however they had $30 \%$ promotional content, $40 \%$ owned content, and $60 \%$ curated content. The rest of the businesses are perceived to be fairly bad at mixing their content, and either always showed the same type of content or did not have the right mix of promotional, owned and curated content.

FrankBody had well-developed image descriptions that are catchy and daring. Furthermore, they used a made-up character, 'Frank', and created the description as it was Frank who wrote it, which made the description very personal and relatable. Other businesses are either posting very long descriptions, such as ThankYou, VegeThreads and LovingEarth, or too short or non-informal descriptions, such as LonelyKidsClub, LiartheLabel or Bisonte.

The average score for the overall image is 2.90. FrankBody, ThankYou and VegeThreads are very good at creating a story on their feed by creating a sense of invitation, attractiveness and creative flow. However, the rest of the businesses are poor at using storytelling on their Instagram profile. Their planning is perceived to be weak, 
had no flow, and is not inviting or attractive to the reviewers. Not all of the companies are familiar with influencer marketing. FrankBody and PressedJuices are the only two businesses that used influencers on a regular basis. The others had a very irregular use which suggests that SMEs do not see the connection between audience reach and influencer marketing. From the analysis, we could ascertain that whenever KeepCup and LovingEarth are using an influencer, they had a great audience reach based on the 'like' figures.

\section{Information}

This dimension overlaps from the above by extending the content appeal to allow visitors and potential customers to contact the SME (Nummila, 2015). Here a recognizable brand image and contact ease would be regarded as crucial.

The average score for this dimension 4.48, shown in Table 3. Almost all SMEs had scored well when it came to attractive Instagram profile (see Figure 3). However, there are noticeable areas that could be improved, especially in Content Appeal. On average, KeepCup is perceived to have failed in numerous areas that are considered important. FrankBody, on the other hand, had perfectly understood the importance of this factor despite not having an overly spectacular score in interactivity which is crucial with modern devices used with Instagram.

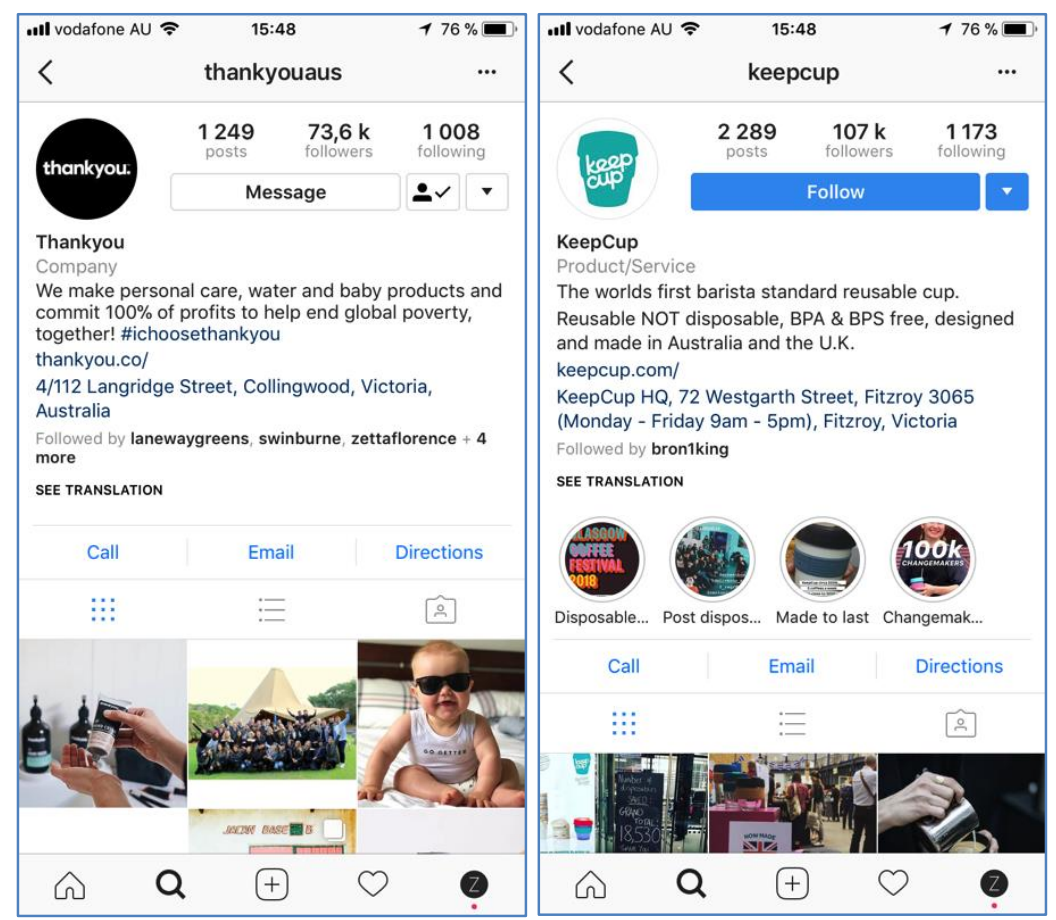

Source: Instagram 2019b and 2019e

Figure 3 Examples of Information on Instagram 


\section{Cultural Awareness}

Knowledge of the local language when entering foreign market helps SME managers in international business, such as better understand the cultural context, collect insightful market information and understand the desires of the local society (Hermeking, 2005, Hofstede, 2001; Le, 2015; Selvarajah, et al., 2019; Sinkovics, Yamin, \& Hossinger, 2007). Berthon et al. (2012) suggest that a major determining factor in social media profiling is how culture is portrayed. From an international marketing strategy point of view, this means that businesses cannot follow a standardized or one-size-fits-all approach when it comes to the usage of social media. Therefore Berthon et al. (2012) suggest that businesses should tailor their social media parts of its global marketing strategy to fit and accommodate the difference among nations and the market they approach. Having a customized site for different types of the market on Instagram will give a competitive edge.

This dimension had sub-categories international readiness and cultural influence on design criteria. The average score for international readiness is 3.20. depicted in Appendix Table 4, and all of them scored 5 for having a site build in English. The average score for local vs. global is 1.40 , and the only businesses that are using multiple Instagram profiles are PressedJuices (for Australia and Hong Kong), ThankYou (Australia and New Zealand) and LovingEarth (Australia, France and the Netherlands, however, these are not all LovingEarth's markets). In terms of cultural influence on design, FrankBody is perceived to be extremely good at using models and influencers from various cultural backgrounds such as Asia, Africa and Australia. Pressed Juice did not change their content much on their Hong Kong profile, and for example the colour scheme is the same. Also, they are using more people from Australia in the content rather than from Asia. LovingEarth did not change their content based on culture. They used the same images and same colour scheme. Furthermore, they did not seem to collaborate with any local influencers. ThankYou also uses similar content for the two markets and the colour scheme is the same. They are not using influencers in either of the markets.

ThankYou are versatile at communicating and in referring to various local news, weather and locations on the two profiles. Furthermore, they are using UGC from New Zealand on their Instagram profile for New Zealand. Similarly, PressedJuices used more visual descriptions, such as including emoji, and more personal touch to their communication. They engage both English and Chinese hashtags and are using more UGC on their Hong Kong profile. LovingEarth used the local languages on the several profiles. However, the hashtags are only in English. Furthermore, they are using the same UGC from Australia for all markets and despite not having more than one 
Instagram profile. FrankBody and LonelyKidsClub are using UGC from customers with different ethnic backgrounds.

\section{Communication}

Communication involving social media is dependent on how conversant the business is when it comes to engagement. Nummila (2015) notes that English is generally used on Instagram, including the hashtags, in order to maximize visibility and attract multilingual users.

The usage of different languages, both in the provided profile information, image description, and hashtags are vital. Regarding interactivity, importance needs to be given to managing UGC (Daugherty, Eastin \& Bright, 2008; Goh, Heng \& Lin, 2013) and overall way of communicating with different cultural audiences (Ting, Cyril de run, \& Lin Liew, 2016).

The average scores for \#hashtags are 3.62 (see Appendix Table 5). All businesses had an official hashtag besides LonelyKidsClub and VegeThreads however LovingEarth's \#lovingearth could not be identified as unique to the business as well as ThankYou's hashtag \#ichoosethankyou. Bisonte did not actually promote an official hashtag, yet it is identified that they used \#bisonteaustralia, which could easily be interpreted as the animal Bisonte (in Spanish) instead of the business. Moreover PressedJuices hashtag \#pressedjuices is very broadly used, yet the brand only appeared in 2 out of 10 images with the hashtag. Regarding the characteristic of not including another brand or product name, the average score is 3.30 and all businesses using official hashtags scored 5 points except for PressedJuices. FrankBody and ThankYou are good at replying to comments, businesses such as KeepCup and PressedJuices barely replied to comments.

\section{Integration}

Social media have elevated the type and level of experience customers gain from their brands supported by emerging technologies. Le (2015) implies that if businesses develop a strong understanding of foreign markets and the requirements, the decisionmaker can make better decisions on which markets to enter and how to adapt their business operations towards omni-channel offering (Lemon \& Verhoef, 2016, Cummins, Peltier \& Dixon, 2016). Capitalizing on Instagram features that allow business to narrate a 'story' about their product will be hugely beneficial as the product becomes more relatable to their customers (Ashley \& Tuten, 2015, Mccann \& Barlow, 2015. Gilbert, 2017, Amâncio 2017, Sugg, 2018).

The integration dimension had the lowest score of 1.70 compared to other dimensions (see Table 3). The main reason could be that none of the SMEs, apart from 
FrankBody, has fully embraced the idea of a business integration solution with Instagram. KeepCup, LovingEarth, LonelyKidsClub and HLSK are using story highlights, however they have only used one story per category. This result is not a strong score for Instagram highlights apart from FrankBody, LonelyKidsClub and HLSK which are seen using linkable stories, where the user can interact. Yet, FrankBody is doing this in all their stories while LonelyKidsClub and HLSK are only using it in a few of their stories. The average score for the shopping experience as shown in Appendix Table 6 is 1.00, which is the same score for the usage of the shopping experience. The only business that is using this feature is FrankBody and HLSK. Moreover FrankBody is the only business that achieved the maximum score of 5.00.

Table 3 Summary of Results

\begin{tabular}{|c|c|c|c|c|c|c|}
\hline & \multicolumn{6}{|c|}{ International marketing dimensions } \\
\hline & $\begin{array}{c}\text { Brand } \\
\text { awareness } \\
\end{array}$ & Information & $\begin{array}{c}\text { Cultural } \\
\text { Awareness }\end{array}$ & $\begin{array}{c}\text { Communi } \\
\text { cation }\end{array}$ & Integration & total \\
\hline $\begin{array}{l}\text { Frank } \\
\text { Body }\end{array}$ & 4.675 & 4.33 & 3.25 & 4.55 & 5 & 4.36 \\
\hline $\begin{array}{l}\text { Loving } \\
\text { Earth }\end{array}$ & 4.167 & 4.58 & 3.75 & 4.51 & 1.33 & 3.67 \\
\hline $\begin{array}{l}\text { Pressed } \\
\text { Juices }\end{array}$ & 4.28 & 4.83 & 4 & 3.03 & $\mathbf{0 . 8 3 3}$ & 3.39 \\
\hline $\begin{array}{c}\text { Thank } \\
\text { You }\end{array}$ & 1.93 & 5 & 4.5 & 4.61 & $\mathbf{0}$ & 3.21 \\
\hline HLSK & 1.14 & 4.36 & 1.25 & 3.74 & 4.67 & 3.03 \\
\hline Keep Cup & 3.08 & 5 & 1.25 & 4.38 & 1.33 & 3.01 \\
\hline $\begin{array}{c}\text { Lonely } \\
\text { Kids Club }\end{array}$ & 0.75 & 5 & 2.75 & 2.57 & 2.17 & 2.65 \\
\hline $\begin{array}{c}\text { Liarthe } \\
\text { Label }\end{array}$ & 2.88 & 4.583 & 1.25 & 3.67 & 0.833 & 2.64 \\
\hline $\begin{array}{c}\text { Vege } \\
\text { Threads }\end{array}$ & 4.36 & 3.61 & 2 & 2.38 & 0.833 & 2.64 \\
\hline Bisonte & 0.98 & 3.5 & 2 & 2.42 & $\mathbf{0}$ & 1.78 \\
\hline Average & 2.82 & 4.48 & 2.6 & 3.59 & 1.70 & 3.04 \\
\hline
\end{tabular}

\section{DISCUSSION AND CONCLUSION}

The content analysis, using the 5 international marketing dimensions, provided an overview on where all the 10 SMEs sat when it came to internationalizing (see Table 4 and Figure 4). Overall results depicted in Table 3 shows that FrankBody (4.36) performed well in comparison to the other nine SMEs KeepCup (3.01), PressedJuices 
(3.39), LovingEarth (3.67) and Thank You (3.21) LiartheLabel (2.64), LonelyKidsClub (2.48), HLSK (3.03), Bisonte (1.78) and VegeThreads (2.64). Based on these scores, we would place FrankBody in an Advance category, Bisonte in the Basic category while the rest could be labelled as Intermediate when it came to Instagram proficiency. It was notable that all ten SMEs had some areas of improvement required (as below) based on the dimensions and sub-dimensions measured. Overall the SMEs performed fairly well regarding information and communication and poorly on brand awareness and integration.

Table 4 SMEs, Instagram Proficiency and Training Required

\begin{tabular}{|c|c|c|}
\hline SMEs & $\begin{array}{l}\text { Instagram } \\
\text { Proficiency }\end{array}$ & Instagram Training Requirements \\
\hline Bisonte & Basic & $\begin{array}{l}\text { Brand awareness, communication, information, } \\
\text { integration and cultural awareness. }\end{array}$ \\
\hline KeepCup & Intermediate & $\begin{array}{l}\text { Brand awareness (the content, image description, overall } \\
\text { image, influencer marketing), integration (Instagram } \\
\text { stories, the shopping experience), cultural awareness (local } \\
\text { vs. global, cultural influence on design criteria) }\end{array}$ \\
\hline PressedJuices & Intermediate & $\begin{array}{l}\text { Communication (hashtags, engagement, activity) } \\
\text { Integration (Instagram stories, the shopping experience) }\end{array}$ \\
\hline LovingEarth & Intermediate & $\begin{array}{l}\text { Integration (Instagram stories, the shopping experience), } \\
\text { cultural awareness (cultural influence on design criteria) }\end{array}$ \\
\hline ThankYou & Intermediate & $\begin{array}{l}\text { Brand awareness (image description), integration } \\
\text { (Instagram stories, the shopping experience) }\end{array}$ \\
\hline LiartheLabel & Intermediate & $\begin{array}{l}\text { Brand Awareness (content, image description, overall } \\
\text { image, influencer marketing), communication } \\
\text { (engagement), integration (Instagram stories, the shopping } \\
\text { experience), cultural awareness (local vs. global, cultural } \\
\text { influence on design criteria) }\end{array}$ \\
\hline LonelyKidsClub & Intermediate & $\begin{array}{l}\text { Brand Awareness (content, image description, overall } \\
\text { image, influencer marketing) communication (hashtags, } \\
\text { engagement), integration (the shopping experience), } \\
\text { cultural awareness (local vs. global, cultural influence on } \\
\text { design criteria) }\end{array}$ \\
\hline HLSK & Intermediate & $\begin{array}{l}\text { Brand awareness (content, image description, influencer } \\
\text { marketing), cultural awareness (local vs. global, cultural } \\
\text { influence on design criteria) }\end{array}$ \\
\hline VegeThreads & Intermediate & $\begin{array}{l}\text { Communication (hashtag, engagement), Information } \\
\text { (basic information), Integration (Instagram stories", the } \\
\text { shopping experience), Cultural Awareness (local vs. } \\
\text { global, cultural influence on design criteria) }\end{array}$ \\
\hline FrankBody & Advance & $\begin{array}{l}\text { Image description, hashtag, engagement (likes and } \\
\text { comments), basic information (phone number), cultural } \\
\text { awareness (local vs. global, interactivity) }\end{array}$ \\
\hline
\end{tabular}


The average score of usage of UGC was high at 3.60. FrankBody, LovingEarth and ThankYou are good at using UGC. FrankBody is for example mostly reposting images from local influencers, with around 2000 followers, using their products. We found that followers are really good at using the hashtags of FrankBody, KeepCup, LovingEarth and ThankYou. When it came to follower's usage of tagging the brands, businesses that were being tagged the most are FrankBody, KeepCup, LovingEarth, ThankYou and LonelyKidsClub. In fact, FrankBody, as well as HLSK, had a lot of users tagging other users. When we examined the activity of the businesses, all businesses had high post frequency and are posting 1-3 times a day except for PressedJuices, HLSK and Bisonte.

It was obvious that most SMEs need to improve their cultural awareness in order to better utilize Instagram as a platform for reaching international markets. They could do so either by adopting local, individual profiles for each market and tailor their content and communication to each culture or including more cultural diversity on their global Instagram profile. The findings are therefore unique to the 10 SMEs but discussion on the 5 dimensions are contextually relevant to most SMEs.

It was also identified that SMEs can be successful internationally despite having local Instagram profiles. Incorporating good cultural diversity like FrankBody in the Instagram feed by using a range of models, variety of UGC and hashtags from various languages, SMEs can internationalize and make their Instagram profile attractive and inviting to a myriad of cultures. Doing this could be more effective than having multiple local Instagram profiles that is not being tailored for market's preferences, such as in content and communication.

In the interest of understanding the training required to bridge the gap between SMEs and larger businesses we benchmarked each item using Selvarajah et al. (2015) 3-tier model of non-exporters, potential exporters and exporters (Figure 4). By addressing the training needs for their specific tier, SMEs can improve their Instagram activity and use it as a platform when internationalizing. By increasing their digital engagement, such as social media engagement, SMEs can become more efficient as well as benefit both themselves and the national economy. 


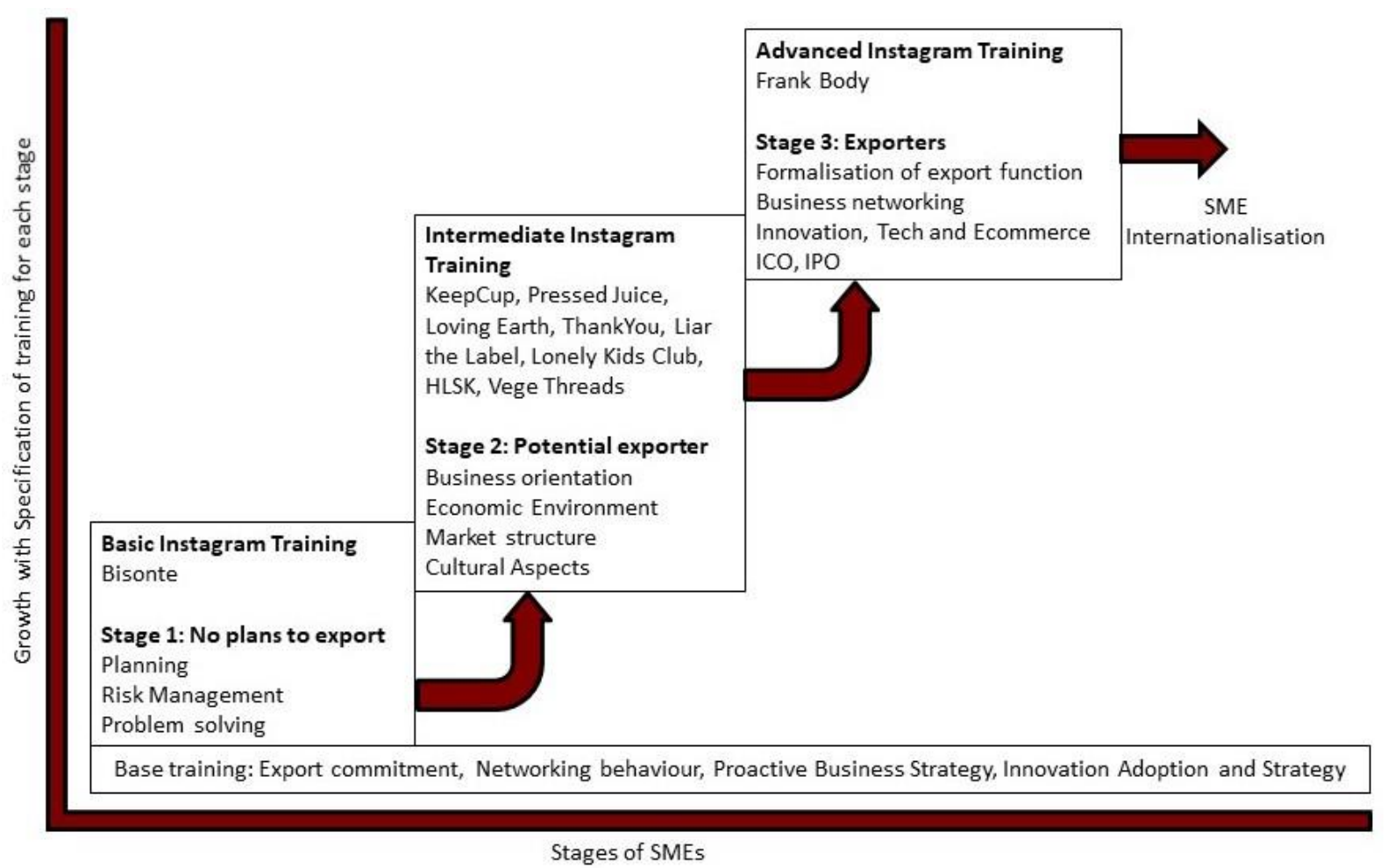

Source: Selvajarah, 2014

\section{Figure 4 Adapted 3-stage SME Internationalisation Model including Instagram}

Social media in general seems to hold the potential for leapfrogging SMEs when it comes to ensuring business competitiveness. In this instance, Instagram has allowed SMEs that have 'invested' well to internationalize. In particular, FrankBody SME internationalization efforts seems to be more structured and formalized. FrankBody's Instagram account could be considered as good as any established large business which shows that SMEs could compete with larger businesses by strategically investing into social media.

\section{Contribution to Theory}

Businesses, especially international commerce is undergoing unprecedented changes as Industrial Revolution 4.0 intensifies. It is within this changes that this article contributes to theory development.

Firstly, this study identifies SMEs as drivers of internationalization strategies of nations. SME internationalization theories have often been overlooked in international business as the discipline of international business has multinational corporations (MNCs) as the drivers of international commerce. There are good reasons for supporting SME internationalization as opposed to purely giving support to MNCs alone. The growth of technology and accesses to digitalization, nations are more supportive of 
knowledge/technology development as opposed to knowledge transfer as a premise for acquiring knowledge for economic growth. SMEs are well placed in this shift.

Secondly, adaptation of social media to commerce has grown exponentially, making it possible for SMEs to utilize the platform to develop businesses globally. A realm that was once with the MNCs. Social media impact studies are relatively new and most of this have been within the marketing discipline. This study clearly demonstrates that the nexus between international business, SME development and technology is an area that will drive the next phase of the industrial revolution.

Thirdly, leapfrogging, as a theoretical concept is strengthened with SME participation in economic growth.

Fourthly, this study contributes knowledge development, specifically in the area of evaluative mechanisms for studying product performance and promotion.

Fifthly, we have demonstrated the importance of identifying training needs to enhance social media usage.

\section{Contribution to Practice}

This study suggests a number of practical benefits.

Firstly, the study proposes that social media has the potential to support business development if proper evaluative mechanisms are used to effectively monitor product and promotion.

Secondly, we have provided a practical framework for social media usage that can be used by organizations to study impact their promotion strategies will have on products.

Thirdly, the framework also provides a training needs analysis to support areas that requires support.

\section{Limitations and Recommendations for future Research}

One of the limitations of this study would be author biased observation. There would have been instances where the information about the SMEs and their Instagram activities perceived in a misleading manner. In future, authors propose to interview participating SMEs to reduce or limit the bias and improve the richness of the data obtained for more insightful analysis. Future research would also include observing all social media footprint for each SME. This would include other platforms, such as Facebook, Twitter, Pinterest, and Linkedin which may contribute to a better identification of necessary training skills required for SMEs internationalization process. 


\section{REFERENCES}

Acedo, F. J., \& Galán, J. L. (2011). Export stimuli revisited: The influence of the characteristics of managerial decision makers on international behaviour. International Small Business Journal, 29, 648-670.

https://doi.org/10.1177/0266242610375771

Al-Abri, M. T., Rahim, A. A., \& Hussain, N. H. (2018). Entrepreneurial ecosystem: An exploration of the entrepreneurship model for SMEs in sultanate of Oman. Mediterranean Journal of Social Sciences, 9(6), 193-206.

https://doi.org/10.2478/mjss-2018-0175

Amâncio, M. (2017). Put it in your story: Digital storytelling in Instagram and snapchat stories (Master's thesis). Uppsala University, Department of Informatics and Media, Uppsala.

Ashley, C., \& Tuten, T. (2015). Creative strategies in social media marketing: An exploratory study of branded social content and consumer engagement. Psychology \& Marketing, 32(1), 15-27. https://doi.org/10.1002/mar.20761

Asia News Monitor. (2018). United Nations/Turkey: UN' Tech Bank' opens in Turkey, to help poor nations' leapfrog development challenges' [Swinburne]. Retrieved from https://search-proquest-com.ezproxy.lib.swin.edu.au/docview/ 2049960427? rfr_id=info\%3Axri\%2Fsid\%3Aprimo

Aslam, M. M., (2006). Are you selling the right colour? A cross-cultural review of colour as a marketing cue. Journal of Marketing Communications, 12(1), 15-30. https://doi.org/10.1080/13527260500247827

Bell, J. (2010). New-wave global firms: Web 2.0 and SME internationalisation, Journal of Marketing Management, 26(3-4), 213-229.

https://doi.org/10.1080/02672571003594648

Berthon, R. P., Pitt, F. L., Plangger, K., \& Shapiro, D. (2012). Marketing meets web 2.0, social media, and creative consumers: Implications for international marketing strategy. Business Horizons, 55(3), 261-271.

https://doi.org/10.1016/j.bushor. 2012.01.007

Bevilacqua, G. (2014, Feb 13). 30/60/10: The golden ratio for social media marketing [Rallyverse Blog]. Retrieved from https://www.rallyverse.com/blog/index.php/3060-10-the-golden-ratio-for-social-media-marketing/

Bhattacharyya, A., \& Agbola, F. W. (2018). Social and environmental reporting and the co-creation of corporate legitimacy. Contemporary Management Research, 14(3), 191-223. https://doi.org/10.7903/cmr.18247

Bianch, C., Glavas, C., \& Mathews, S. (2017). SME international performance in Latin America. Journal of Small Business and Enterprise Development, 24(1), 176-195. https://doi.org/10.1108/jsbed-09-2016-0142 
Bloom, S. (2017, June 5). Small to medium businesses are confident of the future [Canstar]. Retrieved from https://www.canstar.com.au/business-loans/smallmedium-businesses-contributing-half-australias-gdp/

Bourdieu, P. (1977). Outline of a theory of practice. Cambridge: Cambridge University Press. https://doi.org/10.1017/cbo9780511812507

Bourdieu, P. (2013). Outline of a theory of practice. London: Cambridge University press. https://doi.org/10.1017/CBO9780511812507

Boyd, D. M., \& Ellison, N. B. (2008). Social networking sites: Definition, history and scholarship. Journal of Computer-Mediated Communication, 13(1), 210-230. https://doi.org/10.1111/j.1083-6101.2007.00393.x

Brook, I., Weattherston, J., \& Wilkinson, G. (2011). The international business environment: Challenges and changes. 2nd Ed. Harlow: Prentice Hall.

Bruns, A. (2007). Produsage: Towards a broader framework for user-led content creation. Proceedings, Creativity and Cognition, 6, 99-105.

Buckley, J. P., \& Hashai, N. (2009). Formalizing internationalization in the eclectic paradigm. Journal of Internationalization Business Studies, 40(1), 58-70. https://doi.org/10.1057/palgrave.jibs.8400421

Buinac, E., \& Lundberg, J. (2016). Instagram as a marketing tool: A case study about how companies communicate their brands on social media (Bachelor Thesis), Luleå University of Technology.

Cha, K. J., Hwang, T., \& Gregor, S. (2015). An integrative model of IT-enabled organizational transformation: A multiple case study. Management Decision, 53(8), 1755-1770. https://doi.org/10.1108/md-09-2014-0550

Chen, D., \& Li-Hua, R. (2011). Modes of technological leapfrogging - five case studies from China. Journal of Engineering and Technology Management, 28, 93-108. https://doi.org/10.1016/j.jengtecman.2010.12.006

Chen, D., \& Li-Hua, R. (2011). Technological leapfrogging - implications for developing countries, Journal of Engineering and Technology Management, 28(12), 93-108. https://doi.org/10.1016/j.jengtecman.2010.12.006

Chen, L. (2017). International competitiveness and the fourth industrial revolution, Entrepreneurial Business and Economic Review, 5(4), 111-133. http://doi.org/10.15678/EBER.2017.050405

Chong, W. K., Bian, D., \& Zhang, N. (2016). E-marketing services and e-marketing performance: The roles of innovation, knowledge complexity and environmental turbulence in influencing the relationship. Journal of Marketing Management, 32(1/2), 149-178. https://doi.org/10.1080/0267257x.2015.1102758 
Cicic, M., Patterson, P. \& Shoham, A. (2002). Antecedents of international performance: A service firms perspective. European journal of marketing, 36, 1103-1118. https://doi.org/10.1108/03090560210437352

Clark, W.W., \& Isherwood, W. (2010). Inner Mongolia must "leapfrog" the energy mistakes of the western developed nations. Utilities Policy, 18(1), 29-45. https://doi.org/10.1016/j.jup.2007.07.005

Cleverley, M. (2009). Emerging markets: How ICT advances might help developing nations. Communications of the ACM, 52(9), 30-32. https://doi.org/10.1145/1562164.1562177

Coudounaris, D. N. (2018). Typologies of internationalisation pathways of SMEs- what is new?. Review of International Business and Strategy, 28(3-4), 295-316. https://doi.org/10.1108/ribs-12-2017-0119

Cummins, S., Peltier, W. J., \& Dixon, A. (2016). Omni-channel research framework in the context of personal selling and sales management: A review and research extensions. Journal of Research in Interactive Marketing, 10(1), 2-16. https://doi.org/10.1108/jrim-12-2015-0094

Daniel, E. M., \& Wilson, H. N. (2003). The role of dynamic capabilities in e-business transformation. European Journal of Information Systems, 12(4), 282-296. https://doi.org/10.1057/palgrave.ejis.3000478

Daniels, J. D, Rodebaugh, L. H., \& Sullivan, D. P. (2015). International business environments and operations: Global edition. 15th Ed. Edinburgh: Pearson Education Limited.

Daugherty, T., Eastin, M. S., \& Bright, L. (2008). Exploring consumer motivations for creating user-generated content. Journal of Interactive Advertising, 8(2), 16-25. https://doi.org/10.1080/15252019.2008.10722139

Deloitte (2017). Connected small businesses 2017. Google, Deloitte Access Economics. Retrieved from https://www2.deloitte.com/content/dam/Deloitte/au/Documents /Economics/deloitte-au-economics-connected-small-businesses-google161017.pdf

Deloitte (2019). The performance of Small and Medium Sized Businesses in a digital world. Retrieved from https://www2.deloitte.com/content/dam/Deloitte/es/ Documents/Consultoria/The-performance-of-SMBs-in-digital-world.pdf

Dickey, I. J. \& Lewis, W. F. (2010). The evolution (revolution) of social media and social networking as a necessary topic in the marketing curriculum: A case for integrating social media into marketing classes. Society for Marketing Proceedings,140-143. 
DISER (2020). Industry 4.0. Department of industry, science, energy and resources, Australian government. Retrieved from https://www.industry.gov.au/funding-andincentives/industry-40

Doole, I., \& Rowe, R. (2008). International marketing strategy. 5th Ed. London: SouthWestern Cengage Learning.

Dutot, V., \& Bergeron. (2016). From strategic orientation to social media orientation: Improving SME's performance on social media. Journal of Small Business and Enterprise Development, 23(4), 1165-1190.

https://doi.org/10.1108/jsbed-11-2015-0160

Echeverri, P., \& Skalen, P. (2011). Co-creation and co-destruction a practice-theory based study of interactive value formation. Marketing Theory, 11(3), 351-373. https://doi.org/10.1177/1470593111408181

Ferrara, S. (2015). The smart city and the green economy in Europe: A critical approach. Energies, 8, 4724-4734. https://doi.org/10.3390/en8064724

Forsgren, M. (2016). A note on the revisited Uppsala internationalization process model - the implications of business networks and entrepreneurship. Journal of International Business Studies, 47, 1135-1144.

https://doi.org/10.1057/s41267-016-0014-3

Foucault, M. (1977). Discipline and punish: The birth of the prison. London: Penguin. Gallauger, J., \& Ransbothham, S. (2010). Social media and customer dialog management at Starbucks. MIS Quarterly Executive, 9(4), 197-212.

Ghirmai, K. (2011). Driving forces of globalization in emerging market economies developing countries. Asian Economics and Financial Review, 1(2), 83-94.

Giddens, A. (1984). The constitution of society: Outline of the theory of structuration. Cambridge: Polity.

Gilbert, S (2017). How to user Instagram stories highlights to wow your customers [later]. Retrieved from https://later.com/blog/instagram-stories-highlights/

Goh, K. Y., Heng, C. S., \& Lin, Z. (2013). Social media brand community and consumer behavior: Quantifying the relative impact of user- and marketer-generated content. Information Systems Research, 24(1), 88-107.

https://doi.org/10.1287/isre.1120.0469

Goldemberg, J. (2011). Technological leapfrogging in the developing world. Georgetown Journal of International Affairs, 12(1), 135-141.

https://www.jstor.org/stable/43133873

Grochal-Brejdak, M., \& Szymura-Tyc, M. (2018). The internationalisation process of an e-commerce entrepreneurial firm: The inward-outward internationalisation and development of knowledge. Entrepreneurial Business and Economics Review, 6(4), 103-123. https://doi.org/10.15678/eber.2018.060406 
Gullen, J. B., \& Parboteeah, P. K. (2010). International business strategy and the multinational company. Oxon: Routledge Press.

Hellberg, M. (2015). Visual brand communication on Instagram: A study on consumer engagement. (Master's Thesis Department of Marketing). Hanken School of Economics, Helsink.

Hermeking, M. (2005). Culture and internet consumption: Contributions from crosscultural marketing and advertising research. Journal of Computer-Mediated Communication, 11(1), 192-216.

https://doi.org/10.1111/j.1083-6101.2006.tb00310.x

Hofstede, G. (2001). Culture's consequences, 2nd ed., Sage, CA: Thousand Oaks.

Holliman, G., \& Rowley, J. (2014). Business to business digital content marketing: Marketers' perceptions of best practice. Journal of Research in Interactive Marketing, 8(4), 269-293. https://doi.org/10.1108/jrim-02-2014-0013

Hootsuite and We Are Social (2020). Digital in 2020, Hootsuite.

Hosni, H. R. (2020). Advice giving in Egyptian Arabic and American English: A crosslinguistic, cross-cultural study. Journal of Pragmatics, 155, 193-212. https://doi.org/10.1016/j.pragma.2019.11.001

Hultman, M., Katsikeas, S. C., \& Robson, J. M. (2011). Export promotion strategy and performance: The role of international experience. Journal of International Marketing, 19(4), 17-39. https://doi.org/10.1509/jimk.19.4.17

Inkster, N. (2008). Assessing political risk. The Adelphi Papers, 48(400-401), 161-166. https://doi.org/10.1080/05679320802694373

Instagram. (2018). Bringing Shopping on Instagram to more countries, business [Instagram]. Retrieved from https://business.instagram.com/blog/shopping-oninstagram-goes-global/

Instagram. (2019a). FrankBody [Instagram]. Retrieved from https://www.instagram.com/frank_bod/

Instagram. (2019b). КеерCup [Instagram]. Retrieved from https://www.instagram.com/keepcup/

Instagram. (2019c). LovingEarth [Instagram]. Retrieved from https://www.instagram.com/loving_earth/

Instagram. (2019d). PressedJuices [Instagram]. Retrieved from https://www.instagram.com/pressedjuices/

Instagram. (2019e). ThankYou [Instagram]. Retrieved from https://www.instagram.com/thankyouaus/

Instagram. (2019f). LiartheLabel [Instagram]. Retrieved from https://www.instagram.com/liarthelabel/ 
Instagram. (2019g). LonelyKidsClub [Instagram]. Retrieved from https://www.instagram.com/lonelykidsclub69/

Instagram. (2019h). HLSK [Instagram]. Retrieved from https://www.instagram.com/hlsk/

Instagram. (2019i). Bisonte [Instagram]. Retrieved from https://www.instagram.com/bisonte_australia/

Instagram. (2019j). VegeThreads [Instagram]. Retrieved from https://www.instagram.com/vegethreads/

Jarzabkowski, P. \& Bednarek, R. (2018). Toward a social practice theory of relational competing. Strategic Management Journal, 39, 794-829. https://doi.org/10.1002/smj.2724

Johnson, M. (2010). Barriers to innovation adoption: A study of e-markets. Industrial Management \& Data Systems, 110(2), 157-174. https://doi.org/10.1108/02635571011020287

Kaplan, A., \& Haenlein, M. (2010). Users of the world, unite! The challenges and opportunities of social media. Business Horizons, 53, 59-68.

https://doi.org/10.1016/j.bushor.2009.09.003

Karjaluoto, H., \& Huhtamäki, M. (2010). The role of electronic channels in micro-sized brick-and-mortar firms. Journal of Small Business \& Entrepreneurship, 23, 17-38. https://doi.org/10.1080/08276331.2010.10593471

Kuivalainen, O., Sundqvist, S., \& Cadogan, J. W. (2010). Entrepreneurial orientation and international performance: A contingent approach. Progress In International Business Research, 5, 271-298.

https://doi.org/10.1108/s1745-8862(2010) 0000005016

Le, D. T. (2015). Human resource development capacity building: Training needs in internationalising Vietnamese small and medium-sized enterprises (SMEs), (Doctoral thesis, Faculty of Business and Law). Swinburne University of Technology.

Lee, E., Lee, J. A., Moon, J. H., \& Sung, Y. (2015). Pictures speak louder than words: motivations for using Instagram. Cyberpsychology, Behaviour, and Social Networking, 18(9), 552-556. https://doi.org/10.1089/cyber.2015.0157

Lemon, N. K., \& Verhoef, C. P. (2016). Understanding customer experience throughout the customer journey. American Marketing Association, 80(1), 69-96. https://doi.org/10.1509/jm.15.0420

Leonard, J. (2012). How SMEs can punch above their weight [Computing]. Retrieved from http://go.galegroup.com.ezproxy.lib.swin.edu.au/ps/i.do?\&id=GALE| $\mathrm{A} 307423071 \& \mathrm{v}=2.1 \& \mathrm{u}=\mathrm{swinburne} 1 \& \mathrm{it}=\mathrm{r} \& \mathrm{p}=\mathrm{ITOF} \& \mathrm{sw}=\mathrm{w}$ 
Li, L., Su, F., Zhang, W., \& Mao, J-Y. (2018). Digital transformation by SME entrepreneurs - A capability perspective. Information Systems Journal, 28, 11291157. https://doi.org/10.1111/isj.12153

Lin, T. L., Lu, T. Y., Hsieh, M. C., \& Liu, H. Y. (2018). From conception to start-up: Who and what affect female entrepreneurship. Contemporary Management Research, 14(4), 253-276. https://doi.org/10.7903/cmr.17957

Lizardo, O. (2004). The cognitive origins of Bourdieu's habitus. Journal for the Theory of Social Behaviour, 34(4), 375-448.

https://doi.org/10.1111/j.1468-5914.2004.00255.x

Loane, S., \& Bell, J. (2006). Rapid internationalization among entrepreneurial firms in Australia, Canada, Ireland and New Zealand: An extension to the network approach. International Marketing Review, 23(5), 467-485.

https://doi.org/10.1108/02651330610703409

Louart, P., \& Martin, A. (2012). Small and medium-sized enterprises and their attitudes towards internationalization and innovation. International Business Research, 5(6), 14-23. https://doi.org/10.5539/ibr.v5n6p14

Makkonan, H., \& Olkkonen, R. (2017). Interactive value formation in interorganizational relationships - Dynamic interchange between value co-creation, no-creation, and co-destruction. Marketing Theory, 17(4), 517-535. https://doi.org/10.1177/1470593117699661

Makkonen, H., Olkkonen, R., \& Halinen, A. (2012). Organizational buying as muddling through- A practice-theory approach. Journal of Business Research, 65, 773-780. https://doi.org/10.1016/j.jbusres.2010.12.015

Martin-de Castro, G. (2013). Knowledge management and innovation in knowledgebased and high-tech industrial markets: The role of openness and absorptive capacity. Industrial Marketing Management, 47, 143-146.

https://doi.org/10.1016/j.indmarman.2015.02.032

Matenge, T. (2011). Small firm internationalization: A developing country perspective. International Journal of Business Administration, 2(4), 103-111. https://doi.org/ 10.5430/ijba.v2n4p103

Mccann, M., \& Barlow, A. (2015). Use and measurement of social media for SMEs. Journal of Small Business and Enterprise Development, 22(2), 273-287. https://doi.org/10.1108/jsbed-08-2012-0096

McDougall, P. P., \& Oviatt, B. M. (2000). International entrepreneurship: The intersection of two research paths. Academy of Management Journal, 43(5), 902906. https://doi.org/10.5465/1556418 
Meltzer P, J. (2015). Using the internet to promote services exports by small-and medium-sized enterprises. Global Economy and Development at Brookings, 83, 126.

Menon, R. (2006). Late adopters leapfrog ahead of the west financial sectors: By investing in the latest tools, developing nations send a message to the world and help business grow. The Financial Times, 29 March. Retrieved from http://go.galegroup.com.ezproxy.lib.swin.edu.au/ps/i.do?\&id=GALE|A14380264 $6 \& v=2.1 \& u=s w i n b u r n e 1 \& i t=r \& p=A O N E \& s w=w$.

Michaelidou, N., Siamagka, T. N., \& Christodoulides, G. (2011). Usage, barriers and measurement of social media marketing: An exploratory investigation of small and medium B2B brands. Industrial Marketing Management, 40, 1153-1159.

https://doi.org/10.1016/j.indmarman.2011.09.009

Morgan A., N, Katsikeas, S. C. \& Vorhies, W. D. (2012). Export marketing strategy implementation, export marketing capabilities, and export venture performance. Journal of the Academic Marketing Science, 40, 271-289.

https://doi.org/10.1007/s11747-011-0275-0

Morrison, J. (2011). The global business environment: Meeting the challenges. 3rd Ed., Hampshire: Palgrave Macmillan.

Naaman, M., Boase, J., \& Lai, C. (2010). Is it really about me? Message content in social awareness streams. In Proceedings of the 2010 ACM Conference on Computer Supported Cooperative Work - CSCW'10. https://doi.org/10.1145/1718918.1718953

Narula, R. (2010). Keeping the Eclectic Paradigm simple. Multinational Business Review, 18(2), 35-50. https://doi.org/10.1108/1525383X201000009

Nederman, C. J. (1990). Nature, ethics, and the doctrine of 'Habitus': Aristotelian moral psychology in the twelfth century, Traditio, 45, 87-110.

https://doi.org/10.1017/s0362152900012691

Negroponte, N. (1991). The new world economic order: The Nintendo presence. New Perspectives Quarterly, 8(4), 58.

Nummila, M (2015). Successful social media marketing on Instagram (Bachelor Thesis). Haaga-Helia University of Applied Sciences, Helsinki.

Oviatt, B. M., \& McDougal, P. P. (2005). Defining international entrepreneurship and modelling the speed of internationalization. Entrepreneurship: Theory and Practice, 29(5), 537-554. https://doi.org/10.1111/j.1540-6520.2005.00097.x

Oztamur, D., \& Karakadilar, IS. (2015). Exploring the role of social media for SMEsAs a new marketing strategy tool for the firm performance perspective. Procedia: Social \& Behavioural Sciences, 150, 511-520.

https://doi.org/10.1016/j.sbspro.2014.09.067 
Perera, C., Auger, P., \& Klein, J. (2018). Green consumption practices among young environmentalists- A practice theory perspective. Journal of Business Ethics, 152, 843-864. https://doi.org/10.1007/s10551-016-3376-3

Pew Research Center. (2018). Social media use in 2018. Retrieved from https://www.pewresearch.org/internet/2018/03/01/social-media-use-in-2018/

Plé, L. (2017). Why do we need research on value co-destruction?. Journal of Creating Value, 3(2), 162-169. https://doi.org/10.1177/2394964317726451

Prahalad, C. K., \& Ramaswamy, V. (2004). The future of competition: Co-creating unique value with customers. Boston (MA): Harvard Business School Press.

Ramírez, R. (1999). Value co-production: Intellectual origins and implications for practice and research. Strategic Management Journal, 20(4), 49-65. https://doi.org/ 10.1002/(sici)1097-0266(199901)20:1<49::aid-smj20>3.3.co;2-u

Ridgway, J. L., \& Clayton, B. R. (2016). Instagram unfiltered: Exploring associations of body image satisfaction, Instagram \#selfie posting, and negative romantic relationship outcomes. Cyber Psychology, Behaviour and Social Networking, 19(1), 2-7. https://doi.org/10.1089/cyber.2015.0433

Rifkin, J. (2005). The European dream. New York: Penguin Putnam.

Rink, D. R., \& Swan, J. E. (1979). Product life cycle research: A literature review. Journal of Business Research, 7(3), 219-242.

https://doi.org/10.1016/0148-2963(79)90030-4

Rodrigo, P. (2011). The dynamics of Hexis in Aristotle's philosophy. Journal of British Society for Phenomenology, 42(1), 6-17.

https://doi.org/10.1080/00071773.2011.11006728

Roepke, Inge. (2009). Theories of practice-New inspiration for ecological economic studies on consumption. Ecological Economics, 68(10), 2490-2497. https://doi.org/10.1016/j.ecolecon.2009.05.015

Samson, R., Mehta, M., \& Chandani, A. (2014). Impact of online digital communication on customer buying decision. Procedia Economics and Finance, 11, 872-880. https://doi.org/10.1016/s2212-5671(14)00251-2

Saunders, M., Lewis, P., \& Thornhill, A. (2007). Research methods for business students. Harlow: Financial Times/ Prentice Hall.

Schellenberg, M., Harker, M. J., \& Jafari, A. (2018). International market entry mode A systematic literature review. Journal of Strategic Marketing, 27(7), 601-627. https://doi.org/10.1080/0965254X.2017.1339114

Schumpeter, J. (1942). Capitalism, socialism and democracy, New York: Harper.

Schwab, K. (2016). The fourth industrial revolution: What it means, how to respond. World Economic Forum, 14 January. Retrieved from 
https://www.weforum.org/agenda/2016/01/the-fourth-industrial-revolution-whatit-means-and-how-to-respond/

Selvarajah, C., Le, T. D., \& Sukunesan, S. (2019). The Vietnam project: Developing conceptual knowledge on cross-cultural skills for training in SME internationalisation. Asia Pacific Business Review, 25(3), 338-366.

https://doi.org/10.1080/13602381.2019.1598076

Selvarajah, C., Sukunesan, S., Le, V., Le, T. D., \& Meyer, D. (2015). Capacity building to accelerate SME export performance for poverty alleviation and development. Activity Completion Report to the Department of Foreign Affairs and Trade, Public Sector Linkage Program. Canberra: Australian Government. Unpublished.

Sensis (2017). Sensis social media report 2017 [Sensis]. Retrieved from https://www.sensis.com.au/about/our-reports/sensis-social-media-report

Shamsuddoha, A. K., Ali, M. Y., \& Ndubisi, N. O. (2009). Impact of government export assistance on Internationalization of SMEs from developing nations. Journal of Enterprise Information Management, 22(4), 408-422.

https://doi.org/10.1108/17410390910975022

Sharma, D. D., \& Blomstermo, A. (2003). The internalization process of born global: A network view. International Business Review, 13(6), 739-753.

https://doi.org/10.1016/j.ibusrev.2003.05.002

Shenglin, B., Simonelli, F., Ruidong, Z., Bosc, R., \& Wenwei, L. (2017). Digital infrastructure: Overcoming digital divide in emerging economies, G20 Insights The future of work and education in the digital age. Retrieved from https:/www.g20-insights.org/wp-content/uploads/2017/05/Digital_OvercomingDigital-Divide-II.pdf

Shove, E. (2004). Changing human behaviour and lifestyle: A challenge for sustainable consumption? London: Elgar Publishing.

Sinkovics, R. R., Yamin, M., \& Hossinger, M. (2007). Cultural adaptation in cross border e-commerce: A study of German companies. Journal of Electronic Commerce Research, 8(4), 221. https://doi.org/10.1016/j.elerap.2019.100826

Sinkovics, R., \& Bell, J. (2005). Current perspectives on international entrepreneurship and the internet. Journal of International Entrepreneurship, 3(4), 247-249. https://doi.org/10.1007/s10843-006-7853-0

Sinnappan, S., \& Zutshi, S. (2011). Using microblogging to facilitate community of inquiry: An Australian tertiary experience. In Proceedings of ASCILITE 2011, 1123-1135.

Sinnappan, S., Farrell, C., \& Stewart, E. (2010). Priceless tweets! A study on Twitter messages posted during crisis: Black Saturday. ACIS 2010 Proceedings, 39. 
Son, J.-Y., \& Benbasat, I. (2007). Organizational buyers' adoption and use of B2B electronic marketplaces: Efficiency- and legitimacy-oriented perspectives. Journal of Management Information Systems, 24(1), 55-99.

https://doi.org/10.2753/ mis0742-1222240102

Statista.com. (2018). Number of monthly active Instagram users from January 2013 to September 2017 (in millions) [Statista]. Retrieved from https://www.statista.com/ statistics/253577/number-of-monthly-active-instagram-users/

Stenius, K., Mäkelä, K., Miovský, M., \& Gabrhelík, R. (2017). How to write publishable qualitative research. Publishing Addiction Science: A Guide for the Perplexed, 155172. https://doi.org/10.5334/bbd.h.

Sternad, D., Mundschitz, C., \& Knappitsch, E. (2013). A dynamic model of SME international performance capacity: The accelerating function of cooperation effects. Journal of Small Business \& Entrepreneurship, 26(3), 277-297. https://doi.org/10.1080/08276331.2013.803674

Sthapit, E., \& Bjork, P. (2018). Towards a better understanding of interactive value formation: Three value outcomes perspective. Current Issues in Tourism, 23(6), 693-706. https://doi.org/10.1080/13683500.2018.1520821

Suarez, F. F., \& Lanzolla, G. (2008). Considerations for a stronger first mover advantage theory. The Academy of Management Review, 33(1), 269-270. https://doi.org/10.5465/amr.2008.27752960

Sugg, H. (2018). Why Can't I Add Links to My Instagram Stories [infomedia]. Retrieved from https://infomedia.com/blog/instagram-story-links/

Talavera, M. (2014). 10 reasons why influencer marketing is the next big thing [adweek]. Retrieved from http://www.adweek.com/digital/10-reasons-why-influencermarketing -is-the-next-big-thing/

The Economist. (2006). Playing leapfrog [The Economist]. Retrieved from http://go.galegroup.com.ezproxy.lib.swin.edu.au/ps/i.do?id=GALE|A154012746 $\& \mathrm{v}=2.1 \& \mathrm{u}=\mathrm{swinburne} 1 \& \mathrm{it}=\mathrm{r} \& \mathrm{p}=\mathrm{AONE} \& \mathrm{sw}=\mathrm{w}$.

Ting, H., de Run, E. C., \& Liew, L. S. (2016). Intention to use Instagram by generation cohorts: The perspective of developing markets, global business and management research. International Journal of Business Innovation, 8(1), 43-55.

Vargo, S. L., \& Lusch, R. F. (2004). Evolving to a new dominant logic for marketing. Journal of Marketing, 68(1), 1-17. https://doi.org/10.1509/jmkg.68.1.1.24036

Veirman, D. M., Cauberghe, V., \& Hudders, L. (2017). Marketing through Instagram influencers: Impact of number of followers and product divergence on brand attitude. International Journal of Advertising, 36(5), 798-828.

https://doi.org/10.1080/02650487.2017.1348035 
Virtanen, H., Björk, P., \& Sjöströlm, E. (2017). Follow for follow: Marketing of startup company on Instagram. Journal of Small Business and Enterprise Development, 24(3), 468-484. https://doi.org/10.1108/jsbed-12-2016-0202

White, A., Daniel, E., Ward, J., \& Wilson, H. (2007). The adoption of consortium B2B e-marketplaces: An exploratory study. The Journal of Strategic Information Systems, 16(1), 71-103. https://doi.org/10.1016/j.jsis.2007.01.004

Wong, K. (2014). The explosive growth of influencer marketing and what it means for you. Forbes Entrepreneurs. Retrieved from https://www.forbes.com/sites/kylewong/2014/09/10/the-explosive-growth-ofinfluencer-marketing-and-what-it-means-for-you/\#295fc93752ac

Workfast.com.au. (2017). Small \& medium-sized businesses: Vital to Australia's economy. workfast. Retrieved from https://workfast.com.au/blog/sme-vital-australias-economy/

World Bank (2020). Small and medium enterprises (SMEs) Finance: Improving SMEs' access to finance and finding innovative solutions to unlock sources of capital. The World Bank. Retrieved from https://www.worldbank.org/en/topic/smefinance

Yeoh, P. L. (2005). A conceptual framework of antecedents of information search in exporting: Importance of ability and motivation. International Marketing Review, 22, 165-198. https://doi.org/10.1108/02651330510593269

Yip, G. S., Biscarri, J. G., \& Monti, J. A. (2000). The role of the internationalisation process in the performance of newly internationalising firms. Journal of International Marketing, 8(3), 10-35. https://doi.org/10.1509/jimk.8.3.10.19635

Yu, C-MJ., Guan, J-L., Yang, K-P., \& Chiao, Y-C. (2005). Developing the skills for international business management: The implications of the management education opportunity grid. Journal of Teaching in International Business, 16(4), 5-26. https://doi.org/10.1300/j066v16n04_02

Zhang, Y., \& Wildemuth, M. B. (2005). Qualitative analysis of content. Philosophy of Consciousness, 1(2), 1-12.

Zhang, Y., Trusov, M., Stephen, A. T., \& Jamal, Z. (2017). Online shopping and social media: Friends or foes?. Journal of Marketing, 81(6), 24-41.

https://doi.org/10.1509/jm.14.0344

Zhou, L., Wu, W., \& Luo, X. (2007). Internationalization of the performance of bornglobal SMEs: The mediating role of social network. Journal of International Business Studies, 34(4). 673. https://doi.org/10.1057/palgrave.jibs.8400282

Dr. Suku Sukunesan (Corresponding author) is a senior lecturer in Information Systems at Swinburne University of Technology. He also holds the position of program director for masters in Business Information Systems and senior research fellow. He has a keen interest in 
disruptive technologies, social media applications and innovative business models. To date, he has received over $2 \mathrm{M}$ in research funding. His extensive experience in working with SMEs and MNCs gives him a great insight towards the challenges of technology implementation and digitalization across South East Asian countries.

Christopher Selvarajah is professor of International Business at the Faculty of Business and Law at Swinburne University. He has published five books and contributed over 100 refereed articles and cases studies to reputable international journals and as book chapters. His general interest is in management and in international business with a focus on leadership and cultural studies in international HRM. He has acted as consultant to numerous companies in the Asia Pacific region. He has been instrumental in successfully gaining competitive grants for three international projects worth AUD 1.3 million. These are for projects in ASEAN, and the VISGARD nations.

Zelda Mellström is a contract specialist in the mining industry and a research assistant at Swinburne University. Zelda received her bachelor of science in Business and Economics from Luleå University of Technology (Sweden) in 2016 and her masters in International Business from Swinburne University in 2018. Zelda has mainly researched about social media, especially cultural differences in communication on Facebook pages and how SMEs can utilize Instagram as an international marketing tool when internationalizing 


\section{APPENDIX}

Appendix Table 1: The Instagram Checklist Five dimensions of SME Instagram Marketing

\section{Brand awareness}

Buinac and Lundberg, 2016; Holliman and Rowley, 2014; Michaelidou, Siamagka and Christodoulides, 2011; Deloitte, 2017; Ashley and Tuten, 2015; McCann and Barlow, 2015

\begin{tabular}{|c|c|c|}
\hline CATEGORIES & SUB-CATEGORIES & REFERENCES \\
\hline \multirow[t]{14}{*}{$\begin{array}{l}\text { CONTENT MARKETING, } \\
\text { VISUAL } \\
\text { COMMUNICATION }\end{array}$} & & $\begin{array}{l}\text { Holliman and Rowley, 2014; Lee et al., 2015; } \\
\text { Ting, Cyril de run and Ling Liew, 2016; } \\
\text { Nummila, 2015; Virtanen, Björk and } \\
\text { Sjöström ,2017 }\end{array}$ \\
\hline & The Content & \\
\hline & - Quality & Nummila, 2015 \\
\hline & - Significance & Nummila, 2015 \\
\hline & - Emotional Connection & Nummila, 2015 \\
\hline & - Well Framed & Hellberg, 2015 \\
\hline & - Mix of Content & Nummila, 2015; Bevilacqua, 2014 \\
\hline & The Image Description & \\
\hline & - Suitable & Nummila, 2015 \\
\hline & - @ Tagging & Nummila, 2015; Ridgway and Clayton, 2016 \\
\hline & - \#Hashtags & Nummila, 2015; Ridgway and Clayton, 2016 \\
\hline & - Geotags & $\begin{array}{l}\text { Buinac and Lundberg, 2016; Ridgway and } \\
\text { Clayton, 2016; Nummila, } 2018\end{array}$ \\
\hline & Overall Image & \\
\hline & - Story telling & Nummila, 2015 \\
\hline \multirow[t]{5}{*}{$\begin{array}{l}\text { INFLUENCER } \\
\text { MARKETING }\end{array}$} & & $\begin{array}{l}\text { Veriman, Cauberghe and Hudders, 2016; Wong, } \\
\text { 2014; Talavera, 2014; Lee et al., } 2015\end{array}$ \\
\hline & - Usage Of Influencers & $\begin{array}{l}\text { Veriman, Cauberghe and Hudders, 2016; Wong, } \\
\text { 2014; Talavera, 2014; Lee et al., } 2015\end{array}$ \\
\hline & - Audience Reach & $\begin{array}{l}\text { Veriman, Cauberghe and Hudders, 2016; Wong, } \\
\text { 2014; Talavera, } 2014\end{array}$ \\
\hline & - Brand Affinity & Wong, 2014 \\
\hline & - Followers Relationship & $\begin{array}{l}\text { Wong, 2014; Veriman, Cauberghe and Hudders, } \\
2016\end{array}$ \\
\hline
\end{tabular}




\section{Communication}

Nummila, 2015; Zhang, et al., 2017; Michaelidou, Siamagka and Christodoulides, 2011; Deloitte, 2017; Ashley and Tuten, 2015; McCann and Barlow, 2015; Virtanen, Björk and Sjöström ,2017; Ting, Cyril de run and Ling Liew, 2016; Ridgway And Clayton ,2016

\begin{tabular}{|c|c|c|}
\hline CATEGORIES & SUB-CATEGORIES & REFERENCES \\
\hline \multirow[t]{7}{*}{ \#HASHTAGS } & & Ridgway and Clayton, 2016; Nummila, 2015 \\
\hline & - Brief & Nummila, 2015 \\
\hline & - Memorable & Nummila, 2015 \\
\hline & $\begin{array}{l}\text { - Closed To Multiple } \\
\text { Interpretations }\end{array}$ & Nummila, 2015 \\
\hline & - Not Broadly Used & Nummila, 2015 \\
\hline & $\begin{array}{l}\text { - Not Including Another } \\
\text { Brand Or Product Name }\end{array}$ & Nummila, 2015 \\
\hline & - Relevance & Nummila, 2015 \\
\hline \multirow[t]{6}{*}{ ENGAGEMENT } & & $\begin{array}{l}\text { Virtanen, Björk and Sjöström, 2017; Goh, Heng } \\
\text { and Lin, } 2013\end{array}$ \\
\hline & - Likes & $\begin{array}{l}\text { McCann and Barlow, 2015; Virtanen, Björk and } \\
\text { Sjöström, 2017; Ridgway and Clayton, } 2016\end{array}$ \\
\hline & - Comments & $\begin{array}{l}\text { McCann and Barlow, 2015; Virtanen, Björk and } \\
\text { Sjöström, 2017; Ridgway and Clayton, } 2016\end{array}$ \\
\hline & - Replies to Comments & $\begin{array}{l}\text { McCann and Barlow, 2015; Homburg, Ehm and } \\
\text { Artz, } 2015\end{array}$ \\
\hline & - Use Of UGC & $\begin{array}{l}\text { Goh, Heng and Lin, 2013; Daugherty, Eastin and } \\
\text { Bright, } 2008\end{array}$ \\
\hline & $\begin{array}{l}\text { - Followers' Usage of } \\
\text { \#Hashtags } \\
\text { - Followers' usage of } \\
\text { @ Tagging The Brand } \\
\text { - Followers' Usage of } \\
\text { @ Tagging Other Users }\end{array}$ & $\begin{array}{l}\text { Ashley and Tuten, 2015; Ting, Cyril de run and } \\
\text { Ling Liew, 2016; Veriman, Cauberghe and } \\
\text { Hudders, } 2016\end{array}$ \\
\hline \multirow[t]{2}{*}{ ACTIVITY } & & Ting, Cyril de run and Ling Liew, 2016 \\
\hline & - Post Frequency & $\begin{array}{l}\text { Ting, Cyril de run and Ling Liew, 2016; Virtanen, } \\
\text { Björk and Sjöström, } 2017\end{array}$ \\
\hline \multicolumn{3}{|l|}{ 3. Information } \\
\hline \multicolumn{3}{|c|}{$\begin{array}{l}\text { Ting, Cyril de run and Ling Liew, 2016; Ashley and Tuten, 2015; Virtanen, Björk and } \\
\text { Sjöström, } 2017\end{array}$} \\
\hline CATEGORIES & SUB-CATEGORIES & REFERENCES \\
\hline \multirow[t]{12}{*}{$\begin{array}{l}\text { ATTRACTIVE } \\
\text { INSTAGRAM PROFILE }\end{array}$} & & Nummila, 2015 \\
\hline & Basic Information & \\
\hline & - Phone Number & Nummila, 2015 \\
\hline & - Location & Nummila, 2015 \\
\hline & - Email & Nummila, 2015 \\
\hline & - Url & Nummila, 2015 \\
\hline & Profile Picture & \\
\hline & - Supporting Values & Nummila, 2015 \\
\hline & - Easy to Recognise & Nummila, 2015 \\
\hline & $\begin{array}{l}\text { - Logo or Professional } \\
\text { Photo }\end{array}$ & Nummila, 2015 \\
\hline & Brand Name & \\
\hline & - Recognizable & Nummila, 2015 \\
\hline
\end{tabular}




\begin{tabular}{|c|c|c|}
\hline \multicolumn{3}{|l|}{ 4. Integration } \\
\hline \multicolumn{3}{|c|}{$\begin{array}{l}\text { Nummila, 2015; McCann and Barlow, 2015; Ashley and Tuten, 2015; Virtanen, Björk and } \\
\text { Sjöström, } 2017\end{array}$} \\
\hline CATEGORIES & SUB-CATEGORIES & REFERENCES \\
\hline \multirow[t]{5}{*}{$\begin{array}{l}\text { THE CUSTOMER } \\
\text { JOURNEY; OMNI- } \\
\text { CHANNEL MARKETING }\end{array}$} & & $\begin{array}{l}\text { Lemon and Verhoef, 2016; Cummins, Peltier and } \\
\text { Dixon, 2016; Ashley and Tuten, } 2015\end{array}$ \\
\hline & Instagram Stories & Hootsuite \& We are Social, 2020 \\
\hline & $\begin{array}{l}\text { - Usage of Instagram } \\
\text { Stories }\end{array}$ & Amâncio, 2017 \\
\hline & - Usage of Story Highlights & Gilbert, 2017 \\
\hline & $\begin{array}{l}\text { - Usage of Linkable } \\
\text { Stories, "Swipe Up". }\end{array}$ & Sugg, 2018 \\
\hline \multirow[t]{2}{*}{$\begin{array}{l}\text { THE SHOPPING } \\
\text { EXPERIENCE }\end{array}$} & & Instagram, 2018 \\
\hline & $\begin{array}{l}\text { - Usage of Shopping } \\
\text { Experience }\end{array}$ & Instagram, 2018 \\
\hline \multicolumn{3}{|l|}{ 5. Cultural awareness } \\
\hline \multicolumn{3}{|c|}{$\begin{array}{l}\text { Meltzer, 2015; Le, 2015; Hermeking, 2005; Hofstede, 2001; Aslam, 2006; Berthon et al., } \\
\text { 2012; Deloitte, } 2017\end{array}$} \\
\hline CATEGORIES & SUB-CATEGORIES & REFERENCES \\
\hline \multicolumn{3}{|l|}{$\begin{array}{l}\text { INTERNATIONAL } \\
\text { MARKETING }\end{array}$} \\
\hline & Language & Le, 2015 \\
\hline & - English & Nummila, 2015 \\
\hline & Local vs. Global & Hermeking, 2005; Berthon et al., 2012 \\
\hline & $\begin{array}{l}\text { - Instagram Profiles for } \\
\text { Each Country }\end{array}$ & Berthon et al., 2012 \\
\hline \multirow[t]{3}{*}{$\begin{array}{l}\text { CULTURAL INFLUENCE } \\
\text { ON DESIGN CRITERIA }\end{array}$} & & $\begin{array}{l}\text { Hermeking, 2005; Aslam, 2006; Berthon et al., } \\
2012\end{array}$ \\
\hline & - Content Appeal & Hermeking, 2005 \\
\hline & - Interactivity & Hermeking, 2005 \\
\hline
\end{tabular}




\section{Appendix Table 2: Brand Awareness Dimension}

\begin{tabular}{|c|c|c|c|c|c|c|c|c|c|c|c|}
\hline $\begin{array}{l}\text { 1. Brand } \\
\text { Awareness }\end{array}$ & $\begin{array}{c}\text { Frank } \\
\text { Body }\end{array}$ & $\begin{array}{l}\text { Keep } \\
\text { Cup }\end{array}$ & $\begin{array}{c}\text { Pressed } \\
\text { Juices }\end{array}$ & $\begin{array}{l}\text { Loving } \\
\text { Earth }\end{array}$ & $\begin{array}{c}\text { Thank } \\
\text { You }\end{array}$ & $\begin{array}{c}\text { Liarthe } \\
\text { Label }\end{array}$ & $\begin{array}{c}\text { Lonely } \\
\text { Kids } \\
\text { Club }\end{array}$ & HLSK & Bisonte & $\begin{array}{c}\text { Vege } \\
\text { Threads }\end{array}$ & Average \\
\hline $\begin{array}{l}\text { Content marketing/ } \\
\text { Visual } \\
\text { Communication }\end{array}$ & 4.35 & 2.4 & 3.55 & 4.33 & 3.87 & 3.52 & 1.5 & 2.28 & 1.97 & 4.22 & 3.20 \\
\hline The content & 4.8 & 3.2 & 4.4 & 5 & 4.6 & 3.8 & 2 & 3.6 & 2.4 & 4.4 & 3.82 \\
\hline Quality & 5 & 5 & 5 & 5 & 5 & 4 & 4 & 5 & 2 & 5 & 4.5 \\
\hline Significance & 5 & 5 & 5 & 5 & 5 & 5 & 3 & 5 & 4 & 5 & 4.7 \\
\hline $\begin{array}{l}\text { Emotional } \\
\text { Connection }\end{array}$ & 5 & 2 & 5 & 5 & 5 & 5 & 1 & 4 & 4 & 4 & 4 \\
\hline Well Framed & 5 & 2 & 5 & 5 & 5 & 3 & 1 & 3 & 1 & 5 & 3.5 \\
\hline Mix of Content & 4 & 2 & 2 & 5 & 3 & 2 & 1 & 1 & 1 & 2.45 & 2.5 \\
\hline $\begin{array}{l}\text { The image } \\
\text { description }\end{array}$ & 3.25 & 3 & 3.25 & 4 & 2 & 3.75 & 1.5 & 2.25 & 2.5 & 3.25 & 2.88 \\
\hline Suitable & 5 & 3 & 2 & 4 & 4 & 3 & 1 & 4 & 2 & 4 & 3.2 \\
\hline @Tagging & 5 & 5 & 5 & 5 & 2 & 5 & 5 & 2 & 2 & 4 & 4 \\
\hline \#Hashtags & 1 & 4 & 5 & 5 & 1 & 5 & $\mathbf{0}$ & 2 & 4 & 4 & 3.1 \\
\hline Geotags & 2 & 0 & 1 & 2 & 1 & 2 & $\mathbf{0}$ & 1 & 2 & 1 & 1.2 \\
\hline Overall Image & 5 & 1 & 3 & 4 & 5 & 3 & 1 & 1 & 1 & 5 & 2.9 \\
\hline Story Telling & 5 & 1 & 3 & 4 & 5 & 3 & 1 & 1 & 1 & 5 & 2.9 \\
\hline $\begin{array}{l}\text { Influencer } \\
\text { Marketing }\end{array}$ & 5 & 3.75 & 5 & 4 & $\mathbf{0}$ & 2.25 & 0 & 0 & 0 & 4.5 & 2.45 \\
\hline $\begin{array}{l}\text { Usage Of } \\
\text { Influencers }\end{array}$ & 5 & 3 & 5 & 2 & $\mathbf{0}$ & 1 & $\mathbf{0}$ & $\mathbf{0}$ & $\mathbf{0}$ & 3 & 1.9 \\
\hline Audience Reach & 5 & 5 & 5 & 5 & $\mathbf{0}$ & 3 & $\mathbf{0}$ & $\mathbf{0}$ & $\mathbf{0}$ & 5 & 2.8 \\
\hline Brand Affinity & 5 & 3 & 5 & 5 & $\mathbf{0}$ & 1 & $\mathbf{0}$ & $\mathbf{0}$ & $\mathbf{0}$ & 5 & 2.4 \\
\hline $\begin{array}{l}\text { Followers } \\
\text { Relationship }\end{array}$ & 5 & 4 & 5 & 4 & $\mathbf{0}$ & 4 & $\mathbf{0}$ & $\mathbf{0}$ & $\mathbf{0}$ & 5 & 2.7 \\
\hline TOTAL & 4.675 & 3.08 & 4.28 & 4.167 & 1.93 & 2.88 & 0.75 & 1.14 & 0.98 & 4.36 & 2.82 \\
\hline
\end{tabular}


Appendix Table 3: Information Dimension

\begin{tabular}{|c|c|c|c|c|c|c|c|c|c|c|c|}
\hline 2. Information & $\begin{array}{c}\text { Frank } \\
\text { Body }\end{array}$ & $\begin{array}{c}\text { Keep } \\
\text { Cup }\end{array}$ & $\begin{array}{c}\text { Pressed } \\
\text { Juices }\end{array}$ & $\begin{array}{l}\text { Loving } \\
\text { Earth }\end{array}$ & $\begin{array}{c}\text { Thank } \\
\text { You }\end{array}$ & $\begin{array}{l}\text { Liarthe } \\
\text { Label }\end{array}$ & $\begin{array}{c}\text { Lonely } \\
\text { Kids } \\
\text { Club } \\
\end{array}$ & HLSK & Bisonte & $\begin{array}{c}\text { Vege } \\
\text { Threads }\end{array}$ & Average \\
\hline Attractive Instagram Profile & 4.33 & 5 & 4.833 & 4.58 & 5 & 4.583 & 5 & 4.36 & 3.5 & 3.61 & 4.48 \\
\hline Basic Information & 3 & 5 & 4.5 & 3.75 & 5 & 3.75 & 5 & 3.75 & 2.5 & 1.5 & 3.78 \\
\hline Phone Number & $\mathbf{0}$ & 5 & 5 & 5 & 5 & $\mathbf{0}$ & 5 & $\mathbf{0}$ & $\mathbf{0}$ & $\mathbf{0}$ & 2.50 \\
\hline Location & 2 & 5 & 3 & $\mathbf{0}$ & 5 & 5 & 5 & 5 & 5 & $\mathbf{0}$ & 3.10 \\
\hline Email & 5 & 5 & 5 & 5 & 5 & 5 & 5 & 5 & 0 & 5 & 4.20 \\
\hline Url & 5 & 5 & 5 & 5 & 5 & 5 & 5 & 5 & 5 & 1 & 4.50 \\
\hline Profile Picture & 5 & 5 & 5 & 5 & 5 & 5 & 5 & 4.33 & 3 & 4.33 & 4.67 \\
\hline Supporting Values & 5 & 5 & 5 & 5 & 5 & 5 & 5 & 5 & 5 & 5 & 5.00 \\
\hline Easy to Recognise & 5 & 5 & 5 & 5 & 5 & 5 & 5 & 3 & 3 & 5 & 4.60 \\
\hline Logo or Professional Photo & 5 & 5 & 5 & 5 & 5 & 5 & 5 & 5 & 1 & 3 & 4.40 \\
\hline Brand Name & 5 & 5 & 5 & 5 & 5 & 5 & 5 & 5 & 5 & 5 & 5.00 \\
\hline Recognisable & 5 & 5 & 5 & 5 & 5 & 5 & 5 & 5 & 5 & 5 & 5.00 \\
\hline TOTAL & 4.33 & 5 & 4.83 & 4.58 & 5 & 4.583 & 5 & 4.36 & 3.5 & 3.61 & 4.48 \\
\hline
\end{tabular}


Appendix Table 4: Cultural Awareness Dimension

\begin{tabular}{|c|c|c|c|c|c|c|c|c|c|c|c|}
\hline 3. Cultural Awareness & $\begin{array}{c}\text { Frank } \\
\text { Body }\end{array}$ & $\begin{array}{l}\text { Keep } \\
\text { Cup }\end{array}$ & $\begin{array}{l}\text { Pressed } \\
\text { Juices }\end{array}$ & $\begin{array}{l}\text { Loving } \\
\text { Earth }\end{array}$ & $\begin{array}{c}\text { Thank } \\
\text { You }\end{array}$ & $\begin{array}{c}\text { Liarthe } \\
\text { Label }\end{array}$ & $\begin{array}{c}\text { Lonely } \\
\text { Kids } \\
\text { Club }\end{array}$ & HLSK & Bisonte & $\begin{array}{c}\text { Vege } \\
\text { Threads }\end{array}$ & Average \\
\hline International Readiness & 2.5 & 2.5 & 5 & 4.5 & 5 & 2.5 & 2.5 & 2.5 & 2.5 & 2.5 & 3.20 \\
\hline Language & 5 & 5 & 5 & 5 & 5 & 5 & 5 & 5 & 5 & 5 & 5,00 \\
\hline English & 5 & 5 & 5 & 5 & 5 & 5 & 5 & 5 & 5 & 5 & 5,00 \\
\hline Local vs. Global & $\mathbf{0}$ & $\mathbf{0}$ & 5 & 4 & 5 & $\mathbf{0}$ & $\mathbf{0}$ & $\mathbf{0}$ & $\mathbf{0}$ & $\mathbf{0}$ & 1.40 \\
\hline $\begin{array}{l}\text { Instagram Profiles for Each } \\
\text { Country }\end{array}$ & $\mathbf{0}$ & $\mathbf{0}$ & 5 & 4 & 5 & $\mathbf{0}$ & $\mathbf{0}$ & $\mathbf{0}$ & $\mathbf{0}$ & $\mathbf{0}$ & 1.40 \\
\hline $\begin{array}{l}\text { Cultural Influence on Design } \\
\text { Criteria }\end{array}$ & 4 & $\mathbf{0}$ & 3 & 3 & 4 & $\mathbf{0}$ & 3 & $\mathbf{0}$ & 1.5 & 1.5 & 2.00 \\
\hline Content Appeal & 5 & $\mathbf{0}$ & 2 & 2 & 3 & $\mathbf{0}$ & 4 & $\mathbf{0}$ & 3 & 3 & 2.20 \\
\hline Interactivity & 3 & 0 & 4 & 4 & 5 & $\mathbf{0}$ & 2 & 0 & $\mathbf{0}$ & 0 & 1.80 \\
\hline TOTAL & 3.25 & 1.25 & 4 & 3.75 & 4.5 & 1.25 & 2.75 & 1.25 & 2 & 2 & 2.60 \\
\hline
\end{tabular}


Appendix Table 5: Communication Dimension

\begin{tabular}{|c|c|c|c|c|c|c|c|c|c|c|c|}
\hline 4. Communication & $\begin{array}{l}\text { Frank } \\
\text { Body }\end{array}$ & $\begin{array}{l}\text { Keep } \\
\text { Cup }\end{array}$ & $\begin{array}{l}\text { Pressed } \\
\text { Juices }\end{array}$ & LovingEarth & ThankYou & $\begin{array}{c}\text { Liarthe } \\
\text { Label }\end{array}$ & $\begin{array}{l}\text { LonelyKids } \\
\text { Club }\end{array}$ & HLSK & Bisonte & $\begin{array}{c}\text { Vege } \\
\text { Threads }\end{array}$ & Average \\
\hline \#Hashtags & 4.5 & 5 & 3.67 & 4.66 & 4.83 & 5 & $\mathbf{0}$ & 4.67 & 3.83 & $\mathbf{0}$ & 3.62 \\
\hline Brief & 5 & 5 & 5 & 5 & 5 & 5 & $\mathbf{0}$ & 5 & 4 & $\mathbf{0}$ & 3.90 \\
\hline Memorable & 5 & 5 & 5 & 5 & 5 & 5 & $\mathbf{0}$ & 5 & 5 & $\mathbf{0}$ & 4.00 \\
\hline $\begin{array}{l}\text { Closed to Multiple } \\
\text { Interpretations }\end{array}$ & 3 & 5 & 5 & 4 & 4 & 5 & $\mathbf{0}$ & 3 & 2 & $\mathbf{0}$ & 3.10 \\
\hline Not broadly Used & 4 & 5 & 1 & 4 & 5 & 5 & $\mathbf{0}$ & 5 & 5 & $\mathbf{0}$ & 3.40 \\
\hline $\begin{array}{l}\text { Not including Another } \\
\text { Brand or Product Name }\end{array}$ & 5 & 5 & 1 & 5 & 5 & 5 & $\mathbf{0}$ & 5 & 2 & $\mathbf{0}$ & 3.30 \\
\hline Relevance & 5 & 5 & 5 & 5 & 5 & 5 & $\mathbf{0}$ & 5 & 5 & $\mathbf{0}$ & 4.00 \\
\hline Engagement & 4.14 & 3.14 & 2.43 & 3.86 & 4 & 2 & 2.71 & 3.57 & 1.42 & 2.14 & 2.94 \\
\hline Likes & 3 & 2 & 3 & 3 & 3 & 2 & 3 & 5 & 1 & 3 & 2.80 \\
\hline Comments & 1 & 1 & 1 & 3 & 2 & 1 & 1 & 5 & 1 & 1 & 1.70 \\
\hline Replies To Comments & 5 & 1 & 1 & 4 & 5 & 2 & 2 & 2 & 2 & 2 & 2.60 \\
\hline Use of UGC & 5 & 4 & 4 & 5 & 5 & 4 & 4 & 1 & 2 & 2 & 3.60 \\
\hline $\begin{array}{l}\text { Follower's Usage of } \\
\text { \#Hashtags }\end{array}$ & 5 & 5 & 2 & 5 & 5 & 1 & 3 & 3 & 1 & 3 & 3.30 \\
\hline $\begin{array}{l}\text { Follower's Usage of } \\
\text { Tagging the Brand }\end{array}$ & 5 & 5 & 3 & 5 & 5 & 3 & 5 & 4 & 2 & 3 & 4.00 \\
\hline $\begin{array}{l}\text { Follower's Usage of } \\
\text { @ Tagging Other Users }\end{array}$ & 5 & 4 & 3 & 2 & 3 & 1 & 1 & 5 & 1 & 1 & 2.60 \\
\hline Activity & 5 & 5 & 3 & 5 & 5 & 4 & 5 & 3 & 2 & 5 & 4.20 \\
\hline Post Frequency & 5 & 5 & 3 & 5 & 5 & 4 & 5 & 3 & 2 & 5 & 4.20 \\
\hline TOTAL & 4.55 & 4.38 & 3.03 & 4.51 & 4.61 & 3.67 & 2.57 & 3.74 & 2.42 & 2.38 & 3.59 \\
\hline
\end{tabular}


Appendix Table 6: Integration Dimension

\begin{tabular}{|c|c|c|c|c|c|c|c|c|c|c|c|}
\hline 5. Integration & $\begin{array}{c}\text { Frank } \\
\text { Body }\end{array}$ & $\begin{array}{c}\text { Keep } \\
\text { Cup }\end{array}$ & $\begin{array}{c}\text { Pressed } \\
\text { Juices }\end{array}$ & $\begin{array}{l}\text { Loving } \\
\text { Earth }\end{array}$ & $\begin{array}{c}\text { Thank } \\
\text { You }\end{array}$ & $\begin{array}{c}\text { Liarthe } \\
\text { Label }\end{array}$ & $\begin{array}{c}\text { Lonely } \\
\text { Kids } \\
\text { Club } \\
\end{array}$ & HLSK & Bisonte & $\begin{array}{c}\text { Vege } \\
\text { Threads }\end{array}$ & Average \\
\hline $\begin{array}{l}\text { The Customer Journey; Omni } \\
\text { Channel Marketing }\end{array}$ & 5 & 2.66 & 1.67 & 2.67 & $\mathbf{0}$ & 1.67 & 4.33 & 4.33 & $\mathbf{0}$ & 1.66 & 2.40 \\
\hline Instagram Stories & 5 & 2.66 & 1.67 & 2.67 & $\mathbf{0}$ & 1.67 & 4.33 & 4.33 & $\mathbf{0}$ & 1.66 & 2.40 \\
\hline Usage of Instagram Stories & 5 & 5 & 5 & 5 & $\mathbf{0}$ & 5 & 5 & 5 & $\mathbf{0}$ & 5 & 4.00 \\
\hline Usage of Story Highlights & 5 & 3 & $\mathbf{0}$ & 3 & $\mathbf{0}$ & $\mathbf{0}$ & 4 & 4 & $\mathbf{0}$ & $\mathbf{0}$ & 1.90 \\
\hline $\begin{array}{l}\text { Usage of Linkable Stories, "Swipe } \\
\text { Up" }\end{array}$ & 5 & $\mathbf{0}$ & $\mathbf{0}$ & $\mathbf{0}$ & $\mathbf{0}$ & $\mathbf{0}$ & 4 & 4 & $\mathbf{0}$ & $\mathbf{0}$ & 1.30 \\
\hline The Shopping Experience & 5 & $\mathbf{0}$ & $\mathbf{0}$ & $\mathbf{0}$ & $\mathbf{0}$ & $\mathbf{0}$ & $\mathbf{0}$ & 5 & $\mathbf{0}$ & $\mathbf{0}$ & 1.00 \\
\hline Usage of Shopping Experience & 5 & $\mathbf{0}$ & $\mathbf{0}$ & $\mathbf{0}$ & $\mathbf{0}$ & $\mathbf{0}$ & $\mathbf{0}$ & 5 & $\mathbf{0}$ & $\mathbf{0}$ & 1.00 \\
\hline TOTAL & 5 & 1.33 & 0.833 & 1.33 & $\mathbf{0}$ & 0.833 & 2.17 & 4.67 & $\mathbf{0}$ & $\mathbf{0 . 8 3 3}$ & 1.70 \\
\hline
\end{tabular}

